\title{
Geographic and temporal variations in pollen exposure across Europe
}

\begin{tabular}{|c|c|}
\hline Journal: & Allergy \\
\hline Manuscript ID: & ALL-2013-00715.R1 \\
\hline Wiley - Manuscript type: & Original Article: Experimental Allergy and Immunology \\
\hline Date Submitted by the Author: & $\mathrm{n} / \mathrm{a}$ \\
\hline Complete List of Authors: & $\begin{array}{l}\text { Smith, Matthew; Medical University of Vienna, ENT Department } \\
\text { Jäger, Siegfried; Medical University of Vienna, Dept. of Ear, Nose and } \\
\text { Throat Diseases } \\
\text { Berger, Uwe; Medical University of Vienna, ENT Department; Medical } \\
\text { University of Vienna, ENT Department } \\
\text { Sikoparija, Branko; University of Novi Sad, Dept. of Biology and Ecology } \\
\text { Hallsdottir, Margret; Icelandic Inst. of Natural History, Icelandic Inst. of } \\
\text { Natural History } \\
\text { Sauliene, Ingrida; Siauliai University, Environemntal Research Department } \\
\text { Bergmann, Karl; Charite - Uniersitätsmedizin Berlin, Klinik f. Dermatologie } \\
\text { und Allergologie } \\
\text { Pashley, Catherine; University of Leicester, Dept. of Infection, Immunity } \\
\text { and Inflammation } \\
\text { de Weger, Letty; LUMC, Dept of Pulmonology } \\
\text { Majkowska - Wojciechowska, Barbara; Medical University of Lodz, Dpt of } \\
\text { Immunology, Rheumatology and Allergy } \\
\text { Rybnicek, Ondřej; Masaryk Uniersity, Faculty of Medicine } \\
\text { Thibaudon, Michel; Réseau national de surveillance aerobiologique, RNSA } \\
\text { Gehrig, Regula; Fed. Office of Meteorology and Climatology, Meteo Swiss } \\
\text { BONINI, MAIRA; ASL Milano 1, PUBLIC HEALTH } \\
\text { Yankova, Raina; University Hospital Sofia, Clinical Center of Allergology } \\
\text { Damialis, Thanos; Aristotle University of Thesaloniki, Dept. of Ecology } \\
\text { Vokou, Despoina; Aristotle University of Thesaloniki, Dept. of Ecology } \\
\text { Gutierrez-Bustillo, Adela; Universidad Complutense de Madrid, Facultat de } \\
\text { Farmacia } \\
\text { Hoffmann-Sommergruber, Karin; Medical University Vienna, Dept. of } \\
\text { Pathophysiology } \\
\text { van Ree, Ronald; Academic Medical Center, Experimental Immunology }\end{array}$ \\
\hline Keywords : & Asteraceae, Betulaceae, Epidemiology, Oleaceae, Poaceae \\
\hline
\end{tabular}


Smith, M. ${ }^{1}$, Jäger S. ${ }^{1}$, Berger U. ${ }^{1}$, Šikoparija B. ${ }^{2}$, Hallsdottir M. ${ }^{3}$, Sauliene I. ${ }^{4}$, Bergmann, K-

$5 \quad$ Ch. ${ }^{5}$, Pashley, C. H. ${ }^{6}$, de Weger, L. ${ }^{7}$, Majkowska-Wojciechowska, B. ${ }^{8}$, Rybníček O. ${ }^{9}$,

6 Thibaudon M. ${ }^{10}$, Gehrig, R. ${ }^{11}$, Bonini, M. ${ }^{12}$, Yankova R. ${ }^{13}$, Damialis, A. ${ }^{14,15}$, Vokou, D. ${ }^{15}$,

7 Gutiérrez Bustillo, A. M. ${ }^{16}$, Hoffmann-Sommergruber K. ${ }^{17 *}$, van Ree R. ${ }^{18}$

${ }^{1}$ University Department of Ear, Nose and Throat Diseases, Medical University of Vienna, Austria; ${ }^{2}$ Laboratory for Palynology, Department of Biology and Ecology, Faculty of Sciences University of Novi Sad, Novi Sad, Serbia; ${ }^{3}$ Icelandic Institute of Natural History, Iceland; ${ }^{4}$ Siauliai University, Lithuania; ${ }^{5}$ Charité - Universitätsmedizin Berlin, Germany; ${ }^{6}$ Institute for Lung Health, Department of Infection, Immunity and Inflammation, University of Leicester, UK; ${ }^{7}$ Department of Pulmonology, Leiden University Medical Center, Leiden, The Netherlands; ${ }^{8}$ Department of Immunology, Rheumatology and Allergy, Medical University of Lodz, Poland; ${ }^{9}$ Faculty of Medicine, Masaryk University, Brno, Czech Republic; ${ }^{10}$ Réseau National de Surveillance Aérobiologique (R.N.S.A.), France; ${ }^{11}$ Federal Office of Meteorology and Climatology MeteoSwiss, Switzerland; ${ }^{12}$ Local Health Authority, Milan 1, Italy; ${ }^{13}$ Clinical Center of Allergology, University Hospital Sofia, Bulgaria; ${ }^{14}$ University of loannina, Greece; ${ }^{15}$ Department of Ecology, Aristotle University of Thessaloniki, Greece; ${ }^{16}$ Departamento de Biología Vegetal II, Facultad de Farmacia, Universidad Complutense de Madrid, Spain; ${ }^{17}$ Department of Pathophysiology and Allergy Research, Medical University Vienna, Austria;

${ }^{18}$ Department of Experimental Immunology and Department of Otorhinolaryngology, Academic Medical Center, University of Amsterdam, The Netherlands. 
$26{ }^{*}$ Corresponding author: Karin Hoffmann-Sommergruber, Dept. of Pathophysiology and

27 Allergy Research, Medical University of Vienna, AKH-EBO 3Q, Waehringer Guertel 18-20, A-

281090 Vienna, Austria. E-mail: Karin.Hoffmann-Sommergruber@meduniwien.ac.at; Fax: +43-

29 1-40400/5130; Tel: +43-1-40400/5104

30 Key words: Asteraceae, Betulaceae, epidemiology, Oleaceae, Poaceae

31

32

33

20

21

22

23

24

25

26

27

28

29

30

31

32

33

34

35

36

37

38

39

40

41

42

43

44

45

46

47

48

49

50

51

52

53

54

55

56

57

58

59

60 
34

35

36

37

38

39

40

41

42

43

44

45

46

47

48

49

50

51

52

53

54

55

56

57

58

ABSTRACT (248 words)

Background: The EC-funded EuroPrevall project examined the prevalence of food allergy across Europe. A well-established factor in the occurrence of food allergy is primary sensitization to pollen.

Objective: To analyse geographic and temporal variations in pollen exposure, allowing investigating how these variations influence the prevalence and incidence of food allergies across Europe.

Methods: Airborne pollen data for two decades (1990-2009) were obtained from 13 monitoring sites located as close as possible to the EuroPrevall survey centres. Start dates, intensity and duration of Betulaceae, Oleaceae, Poaceae and Asteraceae pollen seasons were examined. Mean, slope of the regression, probability level $(p)$ and dominant taxa $(\%)$ were calculated. Trends were considered significant at $p<0.05$.

Results: On a European scale Betulaceae, in particular Betula, is the most dominant pollen exposure, 2-fold higher than to Poaceae, and > 5-fold higher than to Oleaceae and Asteraceae. Only in Reykjavik, Madrid and Derby was Poaceae the dominant pollen, as was

Oleaceae in Thessaloniki. Weed pollen (Asteraceae) were never dominant, exposure accounted for $>10 \%$ of total pollen exposure only in Siauliai (Artemisia) and Legnano (Ambrosia). Consistent trends towards changing intensity or duration of exposure were not observed, possibly with the exception of (not significant) decreased exposure to Artemisia and increased exposure to Ambrosia.

Conclusions: This is the first comprehensive study quantifying exposure to the major allergenic pollen families Betulaceae, Oleaceae, Poaceae and Asteraceae across Europe. These data can now be used for studies into patterns of sensitization and allergy to pollen and foods.

WORD COUNT: 2457 
59

60

61

62

63

64

65

66

67

68

69

70

71

72

73

74

75

76

77

78

79

80

81

82

83

84

85

\section{INTRODUCTION}

IgE-mediated reactions to foods can occur either as a consequence of primary sensitization

to foods or as a cross-reactive phenomenon by primary sensitization to airborne allergen sources, particularly pollen, the oral allergy-syndrome $(1,2)$. The latter includes reactions to fruits, tree nuts, legumes, vegetables and spices. The main structures responsible for pollenvegetable food IgE cross-reactivity, listed in decreasing order of clinical relevance for food allergy, are the major birch pollen allergen (Bet $v 1$ ) also known as a PR 10 protein, the profilins from grass, tree and weed pollen, and cross-reactive carbohydrate determinants (CCD). Lipid transfer proteins (LTP) are mostly reported as primary sensitizers from food, but have more recently also been described as primary sensitizers in weed pollen, e.g. Artemisia, leading to cross-reactive food allergies (2-4).

The EC funded EuroPrevall project set out to examine the prevalence of food allergy across Europe and to determine factors contributing to the onset and persistence of food allergies such as concomitant pollen exposure (5). To this end, cross-sectional (general population and out-patient clinic) and longitudinal (birth cohort) surveys were carried out in up to 13 cities across Europe $(6,7)$. EuroPrevall focused on twenty-four foods that includes some where the role of cross-reactivity to pollen is well-established, e.g. apple and hazelnut linked to birch pollen Bet $v 1(8,9)$ or melon to pollen profilins $(10)$. For many of the other foods, much less is known about the role of cross-reactivity to pollen.

To get better insight into the role of pollen sensitization in the occurrence of crossreactive allergies to foods across Europe, it is essential to evaluate pollen exposure data on a European scale for a prolonged period of time. This allows qualitative and quantitative differences between countries to be established, which can subsequently be used to search for associations between food sensitization and food allergy found in the EuroPrevall community surveys. In addition, changes over time, possibly linked to climate change or globalization, can be used to explain and predict trends in the incidence of food allergies. In the present study, data of airborne pollen for a 20-year period (1990-2009) were obtained 
from 13 pollen-monitoring sites that were located as close as possible to the survey centres

87

88

89

90

91

92

93

94

95

in EuroPrevall (Fig.1). Centres were chosen to represent different geographic and climatic regions in Europe, including Alpine, Mediterranean, Central, Nordic, and Maritime areas. The focus was on pollen of the Betulaceae and Oleaceae (tree pollen), Poaceae (grass pollen) and Asteraceae (weed pollen).

\section{MATERIALS AND METHODS}

\section{Collection and analysis of pollen data}

Criteria for selecting the pollen-monitoring sites were: (a) where possible, they were located in the same city as the clinical centres involved in EuroPrevall; (b) if this was not possible then selected sites representative of the region with regard to climate and plant species distribution were identified; (c) the station contained the longest available pollen dataset for the region. Pollen data were accessed via the European Aeroallergen Network database (EAN - https://ean.polleninfo.eu/Ean/). A total of 1888 datasets (years of pollen data), from 24 different pollen types were downloaded from EAN and included in the analysis.

Daily average pollen data for the Betulaceae, Oleaceae, Poaceae and Asteraceae families recorded during the period 1990-2009 were collected at 13 pollen-monitoring sites in Europe (Fig. 1), using volumetric spore traps of the Hirst design (11) situated at roof level. Samples were examined by light microscopy using internationally recognised and comparable methods (12). To assess the duration of the pollen season, the start and end of the pollen season were defined using the $95 \%$ method, whereby the season starts on the day when $2.5 \%$ of the season's catch had been recorded and the end occurs when $97.5 \%$ of the total catch had been reached (13). The intensity of the pollen season was defined as the sum of pollen recorded in a season.

The following genera are included in the Betulaceae family: Alnus (alder), Betula (birch), Carpinus (hornbeam), Corylus (hazel) and Ostrya (hop-hornbeam). Due to changes 
112 in taxonomic classification, the Corylaceae family (containing Corylus, Carpinus and Ostrya)

113 is now included within an expanded Betulaceae family (14). Betulaceae pollen grains can be

114 identified to genus level, but the pollen-monitoring site at Legnano (near Milano) recorded

115 them as either Betulaceae or Corylaceae (Table 1).

116 The two genera belonging to the Oleaceae family that are most frequently recorded in 117 the air are Fraxinus (ash) and Olea (olive). In addition, some sites also recorded Forsythia, 118 Ligustrum and Syringa but these are rarely found in air samples. An alternative classification 119 of "other Oleaceae" pollen was occasionally used for Forsythia, Ligustrum and Syringa.

120 Legnano simply identified Oleaceae pollen to family level until 2009 (Table 2).

121 Poaceae (grass) pollen grains are morphologically similar, and most can only be 122 identified to family level by light microscopy. However, it is possible to identify some cereals 123 to genus level. Apart from Poaceae, several pollen-monitoring sites included in this study 124 also recorded Secale cereale and Zea mays. Alternatively, the more generic term "Cerealia 125 pollen type" was used (Table 3).

Pollen grains from the genera Ambrosia (ragweed) and Artemisia (e.g. mugwort) are identifiable by light microscopy and so are usually recorded separately (note that Ambrosia was not present at Reykjavik or Madrid). Some sites record additional taxa such as

129 Cichoriaceae or Taraxacum, but more often sites simply use the family name Asteraceae 130 (Compositae) for pollen types not belonging to the Ambrosia or Artemisia genera (Table 4).

Data preprocessing and statistical analysis

Datasets were examined for missing values and irregularities. Years that contained missing values were removed from the analysis when it was deemed that it had a noticeable effect on the results. For example, the Betulaceae family includes some of the earliest spring flowering trees. Not all pollen-monitoring sites commence monitoring on the $1^{\text {st }}$ January each year and can miss the start of the Corylus and Alnus pollen seasons. Therefore, it was not always 
possible to calculate start dates of the season due to missing values (Table 1). However, the same years could still be included in the analysis of season intensity because the dataset still contained the main peaks of the Alnus and Betula pollen seasons.

The following statistics are presented: the mean, Standard Deviation (SD), slope of the simple linear regression over time, Standard Error of the regression slope (SE), probability level $(p)$ and dominant taxa (\%). Trends were considered significant with probability levels $<0.05$. The calculations were carried out using the statistical software packages SPSS version 12.0 .

\section{RESULTS}

\section{Overall pollen exposure}

Pollen from the Betulaceae family is the most dominant pollen type recorded with total seasonal pollen grains summed up for the 13 centres reaching a mean of 98,180 grains, compared to 42,676 for Poaceae, 19,118 for Oleaceae and only 13,399 for Asteraceae (Fig. 2, Tables 1-4). The sum of mean exposure to the four major families of allergenic pollen (Fig. 2) differed by more than an order of magnitude between the centres with the highest (Zürich) and the lowest (Thessaloniki) exposure.

\section{Betulaceae pollen exposure}

The total Betulaceae pollen count was predominantly made up of Betula pollen at most sites, with mean Betula contributions ranging from $50 \%$ at Strasbourg to $100 \%$ at Reykjavik (Table 1 and Fig.2). The exceptions were Leiden (49\% Alnus), Madrid (62\% Alnus) and Thessaloniki (40\% Carpinus and $41 \%$ Corylus). The sites that recorded the most intensive Betulaceae pollen counts were Łodz, Zurich and Prague (Table 1 and Fig.2). The lowest Betulaceae pollen counts were recorded at Reykjavik, Thessaloniki and Madrid. The sites 
163 with the longest Betulaceae pollen seasons were Leiden, Legnano and Thessaloniki. The 164 sites with the shortest seasons were Reykjavik, Prague and Strasbourg (Table 1).

165 Three pollen-monitoring sites had trends towards significantly earlier start dates of the 166 Betulaceae pollen season; these were Reykjavik, Derby and Sofia (Table 1). Of these, only 167 Reykjavik, and Sofia had significantly longer seasons. Betulaceae pollen counts at Reykjavik 168 also showed a significant trend toward more intensive seasons. The only other site where 169 this occurred was Zurich.

Oleaceae pollen exposure

172 The highest exposure to pollen from the Oleaceae family, almost exclusively to Fraxinus 173 pollen, was observed in Zürich, followed by Strasbourg and Sofia (Table 2 and Fig. 2). No 174 Oleaceae pollen was detected in Reykjavik. Fraxinus pollen was also found in Madrid, but 175 Oleaceae exposure was dominated by Olea $(64 \% \pm 24 \%(S D))$. The sites with the longest 176 Oleaceae pollen seasons were Legnano, Thessaloniki and Madrid where Olea pollen is 177 recorded. The shortest Oleaceae pollen seasons were at Siauliai, Łodz, Prague and Zurich. There were no significant trends in start dates of Oleaceae pollen seasons (Table 2).

179 There was only one significant trend in the duration of Oleaceae pollen season, which was towards shorter seasons in Derby. Similarly, the only significant trend in the amount of Oleaceae recorded annually was at Madrid where seasons were becoming less intense. This did not reach significance when Olea pollen exposure was evaluated separately (slope = -

$18373.70, p=0.117)$.

Poaceae pollen exposure

Derby, Leiden and Legnano recorded the most Poaceae pollen (Table 3 and Fig.2). Whereas the pollen-monitoring sites included in this study with the lowest Poaceae pollen count were 
Reykjavik and Siauliai in the north and Thessaloniki in the south. The longest Poaceae pollen seasons were at Legnano, Thessaloniki and Madrid. The shortest Poaceae pollen seasons were recorded at Reykjavik, Siauliai, and Łodz (Table 3).

Significant trends towards earlier Poaceae pollen seasons were recorded at Reykjavik and Strasbourg. Poaceae pollen seasons at Neustrelitz and Thessaloniki became significantly longer. Conversely, Poaceae pollen seasons at Derby were shown to be becoming significantly shorter. There were also opposite trends observed in the amount of Poaceae pollen recorded annually, with seasons becoming significantly less intense in Leiden and more intense in Legnano (Table 3).

\section{Asteraceae pollen exposure}

By far the highest Asteraceae pollen counts were recorded at Legnano, where Ambrosia pollen accounts for $90 \%$ of the total catch (Table 4 and Fig. 2). The next highest Asteraceae pollen counts were recorded at Siauliai and Prague, where Artemisia pollen dominates (mean $97 \%$ and $82 \%$ at Siauliai and Prague, respectively). The lowest Asteraceae pollen counts were at Reykjavik, Derby and Zurich. The longest Asteraceae pollen seasons were at Derby, Zurich and Madrid. Interestingly, a large proportion of Asteraceae pollen in Zurich (mean 42\%) belonged to "other Asteraceae" (not Ambrosia or Artemisia). These other Asteraceae pollen grains were airborne from April onward and extended the season. The shortest Asteraceae seasons were at Siauliai, Prague and Legnano, where either Ambrosia or Artemisia predominated.

Start dates in Asteraceae pollen seasons were shown to be getting significantly earlier at Derby (Table 4). There were no significant trends in season duration, but Asteraceae pollen seasons were becoming significantly less intense at Derby, Leiden and Strasbourg. Asteraceae pollen counts at Legnano are increasing and there is a 
213 corresponding increase in Ambrosia pollen at the site (slope=105.082; $p=0.147$ ), but the

214 trends are not significant.

215

216

\section{DISCUSSION}

217 Pollen count data are considered to be a proxy for aeroallergen exposure (15). A number of 218 studies have examined regional differences in the timing and magnitude of pollen seasons of 219 different allergenic taxa, such as Alnus (16), Betula (17, 18), Olea (19), Artemisia (20) and 220 the Poaceae family $(21,22)$. However, this is the first comprehensive study that quantifies 221 exposure, in terms of the magnitude and duration of pollen seasons across Europe over 20 222 years, for the Betulaceae, Oleaceae, Poaceae and Asteraceae families. As a consequence 223 of the cross-reactive nature of some of their major and/or minor allergens, these allergenic 224 taxa in Europe (23) have major impact on the prevalence of pollen-associated food allergies.

On a European scale, the greatest exposure was to allergenic pollen from the Betulaceae family. This is largely due to the fact that Betulaceae pollen was the most important at 9 out of the 13 sites included in this study, and mean annual Betulaceae pollen counts exceeded 5000 grains at all 9 of these sites. The second most important pollen type was Poaceae, which was the dominant at 3 out of the 13 sites (Reykjavik, Madrid and Derby). However, in comparison to Betulaceae, mean values of $>5000$ Poaceae pollen grains were only recorded at two sites (Derby and Leiden). Mean annual Oleaceae pollen counts only exceeded 5000 grains at Zürich. It is interesting to note that the results of the GA2LEN skin test study showed that the highest sensitization rate to olive was in Zürich (45.5\%), where Fraxinus is the main Oleaceae pollen in the air (mean contribution $98.6 \%$ ) (4, 24). In general, Asteraceae accounted for $<10 \%$ of the pollen types examined (11 out of 13 centres). The exceptions were Siauliai (16\% - mainly Artemisia) and Legnano (30\% - mainly Ambrosia). Legnano was also the only site where mean annual Asteraceae pollen counts were $>5000$ grains. It is important to note that, because of their relatively large and heavy pollen grains, numbers of some pollen types like Ligustrum (Oleaceae) (25) and Artemisia 
(Asteraceae) (26) can be underestimated at roof level where monitoring stations are usually

situated. However, this is unlikely to change the overall picture of pollen exposure being dominated by Betulaceae and, to a lesser extent, by Poaceae.

\section{ACKNOWLEDGEMENTS}


266 This work was funded by the EC through the EuroPrevall project (FOOD-CT-2005-514000).

267 The authors would also like to thank the following for their expert technical assistance: Iveta 268 Lankova $^{\dagger}$, The National Institute of Public Health, Praha, Czech Republic; J. Corden and W. 269 Millington, Midlands Asthma and Allergy Research Association (MAARA), UK; A. Fairs, 270 Department of Infection, Immunity \& Inflammation, University of Leicester, UK; D. Gioulekas 271 (emeritus professor), Pulmonary Department, G.P. Hospital "G. Papanikolaou”, Aristotle 272 University of Thessaloniki, Greece. C. H. Pashley is supported by the Midlands Asthma and 273 Allergy Research Association (MAARA) and the National Institute for Health Research 274 Leicester Respiratory Biomedical Research Unit and the views expressed are those of the 275 author(s) and not necessarily those of the NHS, the NIHR or the Department of Health.

276 Authors Contribution to the work:

277 The project outline was drafted by RvR, MS, SJ, UB and KHS. The data acquisition and 278 coordination of pollen sets was performed by BS, MS SJ, and UB. Finally all the authors MS, 279 SJ, UB, BS, MH, IS, KB, CHP, LW, BMW, OR, MT, RG, MB, RY, AD, DV, AMGB, KHS and 280 RvR provided substantial contributions to conception and design of the study, acquired data 281 or analysed and interpreted data. Subsequently they all provided input to drafting the article 282 and revising it critically for important intellectual content and gave final approval of the 283 version to be published.

284 Conflict of Interest:

285 None of the authors declared a conflict of interest in relation to the current manuscript.

286

FIGURE LEGENDS

Fig. 1. Location of EuroPrevall allergy centres and pollen-monitoring sites 289 
290 Fig. 2 Pollen exposure across Europe. The size of each circle represents the mean 291 exposure level to all four pollen families (Betulaceae, Oleaceae, Poaceae and Asteraceae) 292 together (mean yearly sum of daily pollen concentrations shown in parenthesis) in the 293 thirteen centres across Europe, ranging from 2,565 in Thessaloniki to 28,177 in Zurich. The 294 pie charts illustrate the relative importance (\% indicated) of each of the four main families of 295 allergenic pollen per centre.

296

297

REFERENCES

298

299

1. Burks AW, Tang M, Sicherer S, Muraro A, Eigenmann PA, Ebisawa M, et al. ICON:

300 Food allergy. J Allergy Clin Immunol 2012;129(4):906-920.

301

2. Chapman JA, Bernstein I, Lee RE, Oppenheimer J, Nicklas RA, Portnoy JM, et al.

302

303

304

305

306

307

308

309

310

311

312 Food allergy: a practice parameter. Ann Allergy Asthma Immunol 2006;96(3, Suppl. 2).

3. Lombardero M, García-Sellés FJ, Polo F, Jimeno L, Chamorro MJ, García-Casado G, et al. Prevalence of sensitization to Artemisia allergens Art v 1, Art v 3 and Art v 60 kDa.

Cross-reactivity among Art v 3 and other relevant lipid-transfer protein allergens. Clin Exp Allergy 2004;34(9):1415-1421.

4. Heinzerling LM, Burbach GJ, Edenharter G, Bachert C, Bindslev-Jensen C, Bonini S, et al. GA2LEN skin test study I: GA²LEN harmonization of skin prick testing: novel sensitization patterns for inhalant allergens in Europe. Allergy 2009;64(10):1498-1506.

5. Mills ENC, Mackie AR, Burney P, Beyer K, Frewer L, Madsen C, et al. The prevalence, cost and basis of food allergy across Europe. Allergy 2007;62(7):717-722.

313 EuroPrevall birth cohort study on food allergy: baseline characteristics of 12,000 newborns

314 and their families from nine European countries. Ped Allergy Immunol 2012;23(3):230-239. 
315 7. Kummeling I, Mills ENC, Clausen M, Dubakiene R, Pérez CF, Fernández-Rivas M, et

316 al. The EuroPrevall surveys on the prevalence of food allergies in children and adults:

317 background and study methodology. Allergy 2009;64(10):1493-1497.

318 8. Fernández-Rivas M, Bolhaar S, González-Mancebo E, Asero R, van Leeuwen A,

319 Bohle B, et al. Apple allergy across Europe: How allergen sensitization profiles determine the 320 clinical expression of allergies to plant foods. J Allergy Clin Immunol 2006;118(2):481-488.

321 9. Skamstrup Hansen K, Ballmer-Weber BK, Sastre J, Lidholm J, Andersson K,

322 Oberhofer $\mathrm{H}$, et al. Component-resolved in vitro diagnosis of hazelnut allergy in Europe. $J$

323 Allergy Clin Immunol 2009;123(5):1134-1141.e1133.

324 10. Pastor C, Cuesta-Herranz J, Cases B, Pérez-Gordo M, Figueredo E, de las Heras M, 325 et al. Identification of Major Allergens in Watermelon. Int Arch Allergy Immunol

$3262009 ; 149(4): 291-298$.

327 11. Hirst JM. An automatic volumetric spore trap. Ann Appl Biol 1952;39(2):257-265.

328 12. Cariñanos P, Emberlin J, Galán C, Dominguez Vilches E. Comparison of two pollen

329 counting methods of slides from a Hirst type volumetric trap. Aerobiologia 2000;16(3/4):339-

330346.

331 13. Goldberg C, Buch H, Moseholm L, Weeke EV. Airborne pollen records in Denmark, 332 1977-1986. Grana 1988;27:209-217.

333 14. APGIII. An update of the Angiosperm Phylogeny Group classification for the orders 334 and families of flowering plants: APG III. Bot J Linn Soc 2009;161:105-121.

335 15. Buters JTM, Thibaudon M, Smith M, Kennedy R, Rantio-Lehtimäki A, Albertini R, et 336 al. Release of Bet $v 1$ from birch pollen from 5 European countries. Results from the 337 HIALINE study. Atmos Environ 2012;55:496-505.

338 16. Smith M, Emberlin J, Stach A, Czarnecka-Operacz M, Jenerowicz D, Silny W. The 339 regional importance of Alnus pollen as an aeroallergen: A comparative study of Alnus pollen 340 counts from Worcester (UK) and Poznań (Poland). Ann Agric Environ Med 2007(14):123341128. 
342 17. Emberlin J, Detandt M, Gehrig R, Jaeger S, Nolard N, Rantio-Lehtimäki A.

343 Responses in the start of Betula (birch) pollen seasons to recent changes in spring

344 temperatures across Europe. Int J Biometeorol 2002;46:159-170.

345 18. Stach A, Emberlin J, Smith M, Adams-Groom B, Myszkowska D. Factors that

346 determine the severity of Betula spp. pollen seasons in Poland (Poznań and Krakow) and the

347 United Kingdom (Worcester and London). Int J Biometeorol 2008;52(4):311-321.

348 19. Díaz de la Guardia C, Alba F, Del Mar Trigo M, Galán C, Ruíz L, Sabariego S.

349 Aerobiological analysis of Olea europaea L. pollen in different localities of southern Spain.

350 Grana 2003;42(4):234-243.

351 20. Grewling Ł, Šikoparija B, Skjøth CA, Radišić $P$, Apatini D, Magyar D, et al. Variation

352 in Artemisia pollen seasons in Central and Eastern Europe. Agric For Meteorol

$353 \quad 2012 ; 160(0): 48-59$.

354 21. Emberlin J, Jaeger S, Dominguez Vilches E, Galan Soldevilla C, Hodal L, Mandrioli P, 355 et al. Temporal and geographical variations in grass pollen seasons in areas of western

356 Europe: and analysis of season dates at sites of the European pollen information system.

357 Aerobiologia 2000;16:373-379.

358 22. Smith M, Emberlin J, Stach A, Rantio-Lehtimäki A, Caulton E, Thibaudon M, et al.

359 Influence of the North Atlantic Oscillation on grass pollen counts in Europe. Aerobiologia

$360 \quad 2009 ; 25(4): 321-332$.

361 23. Skjøth CA, Šikoparija B, Jäger S, EAN. Pollen Sources. In: Sofiev M, Bergmann K-C, 362 editors. Allergenic Pollen: Springer Netherlands; 2013. p. 9-27.

363 24. Burbach GJ, Heinzerling LM, Edenharter G, Bachert C, Bindslev-Jensen C, Bonini S, 364 et al. GA2LEN skin test study II: clinical relevance of inhalant allergen sensitizations in 365 Europe. Allergy 2009;64(10):1507-1515.

366 25. Cariñanos P, Alcázar P, Galán C, Domínguez E. Privet pollen (Ligustrum sp.) as 367 potential cause of pollinosis in the city of Cordoba, south-west Spain. Allergy 2002;57(2):9236897. 
369 26. Spieksma FT, van Noort P, Nikkels H. Influence of nearby stands of Artemisia on

370 street-level versus roof-top-level ratio's of airborne pollen quantities. Aerobiologia

$3712000 ; 16: 21-24$.

372 27. Ziello C, Sparks TH, Estrella N, Belmonte J, Bergmann KC, Bucher E, et al. Changes

373 to airborne pollen counts across europe. PLoS ONE 2012;7(4): e34076.

374 doi:34010.31371/journal.pone.0034076.

375 28. Emberlin J, Mullins J, Cordon J, Millington W, Brooke M, Savage M, et al. The trend

376 to earlier birch pollen seasons in the UK: a biotic response to changes in weather conditions?

377 Grana 1997;36: 29-33.

378 29. Newnham RM, Sparks TH, Skjøth CA, Head K, Adams-Groom B, Smith M. Pollen

379 season and climate: Is the timing of birch pollen release in the UK approaching its limit? Int $J$

380 Biometeorol 2012;57(3):391-400.

381 30. Burney PGJ, Potts J, Kummeling I, Mills ENC, Clausen M, Dubakiene R, et al. The

382 prevalence and distribution of food sensitization in European adults. Allergy 2013:doi:

383 10.1111/all.12341. 
1

Short Title - Pollen exposure across Europe: Analysis of 2 decades

Geographic and temporal variations in pollen exposure across Europe

Smith, M. ${ }^{1}$, Jäger S. ${ }^{1}$, Berger U. ${ }^{1}$, Šikoparija B. ${ }^{2}$, Hallsdottir M. ${ }^{3}$, Sauliene I. ${ }^{4}$, Bergmann, KCh. ${ }^{5}$, Pashley, C. H. ${ }^{6}$, de Weger, L. ${ }^{7}$, Majkowska-Wojciechowska, B. ${ }^{8}$, Rybníček O. ${ }^{9}$, Thibaudon M. ${ }^{10}$, Gehrig, R. ${ }^{11}$, Bonini, M. ${ }^{12}$, Yankova R. ${ }^{13}$, Damialis, A. ${ }^{14,15}$, Vokou, D. ${ }^{15}$, Gutiérrez Bustillo, A. M. ${ }^{16}$, Hoffmann-Sommergruber K. ${ }^{17 *}$, van Ree R. ${ }^{18}$

${ }^{1}$ University Department of Ear, Nose and Throat Diseases, Medical University of Vienna, Austria; ${ }^{2}$ Laboratory for Palynology, Department of Biology and Ecology, Faculty of Sciences University of Novi Sad, Novi Sad, Serbia; ${ }^{3}$ Icelandic Institute of Natural History, Iceland; ${ }^{4}$ Siauliai University, Lithuania; ${ }^{5}$ Charité - Universitätsmedizin Berlin, Germany; ${ }^{6}$ Institute for Lung Health, Department of Infection, Immunity and Inflammation, University of Leicester, UK; ${ }^{7}$ Department of Pulmonology, Leiden University Medical Center, Leiden, The Netherlands; ${ }^{8}$ Department of Immunology, Rheumatology and Allergy, Medical University of Lodz, Poland; ${ }^{9}$ Faculty of Medicine, Masaryk University, Brno, Czech Republic; ${ }^{10}$ Réseau National de Surveillance Aérobiologique (R.N.S.A.), France; ${ }^{11}$ Federal Office of Meteorology and Climatology MeteoSwiss, Switzerland; ${ }^{12}$ Local Health Authority, Milan 1, Italy; ${ }^{13}$ Clinical Center of Allergology, University Hospital Sofia, Bulgaria; ${ }^{14}$ University of loannina, Greece; ${ }^{15}$ Department of Ecology, Aristotle University of Thessaloniki, Greece; ${ }^{16}$ Departamento de Biología Vegetal II, Facultad de Farmacia, Universidad Complutense de Madrid, Spain; ${ }^{17}$ Department of Pathophysiology and Allergy Research, Medical University Vienna, Austria;

${ }^{18}$ Department of Experimental Immunology and Department of Otorhinolaryngology, Academic Medical Center, University of Amsterdam, The Netherlands. 
26 *Corresponding author: Karin Hoffmann-Sommergruber, Dept. of Pathophysiology and

27 Allergy Research, Medical University of Vienna, AKH-EBO 3Q, Waehringer Guertel 18-20, A-

281090 Vienna, Austria. E-mail: Karin.Hoffmann-Sommergruber@meduniwien.ac.at; Fax: +43-

29 1-40400/5130; Tel: +43-1-40400/5104

30 Key words: Asteraceae, Betulaceae, epidemiology, Oleaceae, Poaceae

31

32

33

20

21

22

23

24

25

26

27

28

29

30

31

32

33

34

35

36

37

38

39

40

41

42

43

44

45

46

47

48

49

50

51

52

53

54

55

56

57

58

59

60 
34

35

36

37

38

39

40

41

42

43

44

45

46

47

48

49

50

51

52

53

54

55

56

57

58

\section{ABSTRACT (248 words)}

Background: The EC-funded EuroPrevall project examined the prevalence of food allergy across Europe. A well-established factor in the occurrence of food allergy is primary sensitization to pollen.

Objective: To analyse geographic and temporal variations in pollen exposure, allowing investigating how these variations influence the prevalence and incidence of food allergies across Europe.

Methods: Airborne pollen data for two decades (1990-2009) were obtained from 13 monitoring sites located as close as possible to the EuroPrevall survey centres. Start dates, intensity and duration of Betulaceae, Oleaceae, Poaceae and Asteraceae pollen seasons were examined. Mean, slope of the regression, probability level $(p)$ and dominant taxa $(\%)$ were calculated. Trends were considered significant at $p<0.05$.

Results: On a European scale Betulaceae, in particular Betula, is the most dominant pollen exposure, 2-fold higher than to Poaceae, and > 5-fold higher than to Oleaceae and Asteraceae. Only in Reykjavik, Madrid and Derby was Poaceae the dominant pollen, as was

Oleaceae in Thessaloniki. Weed pollen (Asteraceae) were never dominant, exposure accounted for $>10 \%$ of total pollen exposure only in Siauliai (Artemisia) and Legnano (Ambrosia). Consistent trends towards changing intensity or duration of exposure were not observed, possibly with the exception of (not significant) decreased exposure to Artemisia and increased exposure to Ambrosia.

Conclusions: This is the first comprehensive study quantifying exposure to the major allergenic pollen families Betulaceae, Oleaceae, Poaceae and Asteraceae across Europe. These data can now be used for studies into patterns of sensitization and allergy to pollen and foods.

WORD COUNT: 2457 
59

60

61

62

63

64

65

66

67

68

69

70

71

72

73

74

75

76

77

78

79

80

81

82

83

84

85

\section{INTRODUCTION}

IgE-mediated reactions to foods can occur either as a consequence of primary sensitization

to foods or as a cross-reactive phenomenon by primary sensitization to airborne allergen sources, particularly pollen, the oral allergy-syndrome $(1,2)$. The latter includes reactions to fruits, tree nuts, legumes, vegetables and spices. The main structures responsible for pollenvegetable food IgE cross-reactivity, listed in decreasing order of clinical relevance for food allergy, are the major birch pollen allergen (Bet $v 1$ ) also known as a PR 10 protein, the profilins from grass, tree and weed pollen, and cross-reactive carbohydrate determinants (CCD). Lipid transfer proteins (LTP) are mostly reported as primary sensitizers from food, but have more recently also been described as primary sensitizers in weed pollen, e.g. Artemisia, leading to cross-reactive food allergies (2-4).

The EC funded EuroPrevall project set out to examine the prevalence of food allergy across Europe and to determine factors contributing to the onset and persistence of food allergies such as concomitant pollen exposure (5). To this end, cross-sectional (general population and out-patient clinic) and longitudinal (birth cohort) surveys were carried out in up to 13 cities across Europe $(6,7)$. EuroPrevall focused on twenty-four foods that includes some where the role of cross-reactivity to pollen is well-established, e.g. apple and hazelnut linked to birch pollen Bet $v 1(8,9)$ or melon to pollen profilins $(10)$. For many of the other foods, much less is known about the role of cross-reactivity to pollen.

To get better insight into the role of pollen sensitization in the occurrence of crossreactive allergies to foods across Europe, it is essential to evaluate pollen exposure data on a European scale for a prolonged period of time. This allows qualitative and quantitative differences between countries to be established, which can subsequently be used to search for associations between food sensitization and food allergy found in the EuroPrevall community surveys. In addition, changes over time, possibly linked to climate change or globalization, can be used to explain and predict trends in the incidence of food allergies. In the present study, data of airborne pollen for a 20-year period (1990-2009) were obtained 
from 13 pollen-monitoring sites that were located as close as possible to the survey centres

87

88

89

90

91

92

93

94

95

96

97

in EuroPrevall (Fig.1). Centres were chosen to represent different geographic and climatic regions in Europe, including Alpine, Mediterranean, Central, Nordic, and Maritime areas. The focus was on pollen of the Betulaceae and Oleaceae (tree pollen), Poaceae (grass pollen) and Asteraceae (weed pollen).

\section{MATERIALS AND METHODS}

\section{Collection and analysis of pollen data}

Criteria for selecting the pollen-monitoring sites were: (a) where possible, they were located in the same city as the clinical centres involved in EuroPrevall; (b) if this was not possible then selected sites representative of the region with regard to climate and plant species distribution were identified; (c) the station contained the longest available pollen dataset for the region. Pollen data were accessed via the European Aeroallergen Network database (EAN - https://ean.polleninfo.eu/Ean/). A total of 1888 datasets (years of pollen data), from 24 different pollen types were downloaded from EAN and included in the analysis.

Daily average pollen data for the Betulaceae, Oleaceae, Poaceae and Asteraceae families recorded during the period 1990-2009 were collected at 13 pollen-monitoring sites in Europe (Fig. 1), using volumetric spore traps of the Hirst design (11) situated at roof level. Samples were examined by light microscopy using internationally recognised and comparable methods (12). To assess the duration of the pollen season, the start and end of the pollen season were defined using the $95 \%$ method, whereby the season starts on the day when $2.5 \%$ of the season's catch had been recorded and the end occurs when $97.5 \%$ of the total catch had been reached (13). The intensity of the pollen season was defined as the sum of pollen recorded in a season.

The following genera are included in the Betulaceae family: Alnus (alder), Betula (birch), Carpinus (hornbeam), Corylus (hazel) and Ostrya (hop-hornbeam). Due to changes 
112 in taxonomic classification, the Corylaceae family (containing Corylus, Carpinus and Ostrya)

113 is now included within an expanded Betulaceae family (14). Betulaceae pollen grains can be

114 identified to genus level, but the pollen-monitoring site at Legnano (near Milano) recorded

115 them as either Betulaceae or Corylaceae (Table 1).

116 The two genera belonging to the Oleaceae family that are most frequently recorded in 117 the air are Fraxinus (ash) and Olea (olive). In addition, some sites also recorded Forsythia, 118 Ligustrum and Syringa but these are rarely found in air samples. An alternative classification 119 of "other Oleaceae" pollen was occasionally used for Forsythia, Ligustrum and Syringa.

120 Legnano simply identified Oleaceae pollen to family level until 2009 (Table 2).

121 Poaceae (grass) pollen grains are morphologically similar, and most can only be 122 identified to family level by light microscopy. However, it is possible to identify some cereals 123 to genus level. Apart from Poaceae, several pollen-monitoring sites included in this study 124 also recorded Secale cereale and Zea mays. Alternatively, the more generic term "Cerealia 125 pollen type" was used (Table 3).

Pollen grains from the genera Ambrosia (ragweed) and Artemisia (e.g. mugwort) are identifiable by light microscopy and so are usually recorded separately (note that Ambrosia was not present at Reykjavik or Madrid). Some sites record additional taxa such as

129 Cichoriaceae or Taraxacum, but more often sites simply use the family name Asteraceae 130 (Compositae) for pollen types not belonging to the Ambrosia or Artemisia genera (Table 4).

Data preprocessing and statistical analysis

Datasets were examined for missing values and irregularities. Years that contained missing values were removed from the analysis when it was deemed that it had a noticeable effect on the results. For example, the Betulaceae family includes some of the earliest spring flowering trees. Not all pollen-monitoring sites commence monitoring on the $1^{\text {st }}$ January each year and can miss the start of the Corylus and Alnus pollen seasons. Therefore, it was not always 
possible to calculate start dates of the season due to missing values (Table 1). However, the same years could still be included in the analysis of season intensity because the dataset still contained the main peaks of the Alnus and Betula pollen seasons.

The following statistics are presented: the mean, Standard Deviation (SD), slope of the simple linear regression over time, Standard Error of the regression slope (SE), probability level $(p)$ and dominant taxa (\%). Trends were considered significant with probability levels $<0.05$. The calculations were carried out using the statistical software packages SPSS version 12.0.

\section{RESULTS}

\section{Overall pollen exposure}

Pollen from the Betulaceae family is the most dominant pollen type recorded with total seasonal pollen grains summed up for the 13 centres reaching a mean of 98,180 grains, compared to 42,676 for Poaceae, 19,118 for Oleaceae and only 13,399 for Asteraceae (Fig.

2, Tables 1-4). The sum of mean exposure to the four major families of allergenic pollen (Fig.

2) differed by more than an order of magnitude between the centres with the highest (Zürich) and the lowest (Thessaloniki) exposure.

\section{Betulaceae pollen exposure}

157 The total Betulaceae pollen count was predominantly made up of Betula pollen at most sites, 158 with mean Betula contributions ranging from $50 \%$ at Strasbourg to $100 \%$ at Reykjavik (Table 1591 and Fig.2). The exceptions were Leiden (49\% Alnus), Madrid (62\% Alnus) and 160 Thessaloniki (40\% Carpinus and 41\% Corylus). The sites that recorded the most intensive 161 Betulaceae pollen counts were Łodz, Zurich and Prague (Table 1 and Fig.2). The lowest Betulaceae pollen counts were recorded at Reykjavik, Thessaloniki and Madrid. The sites 
163 with the longest Betulaceae pollen seasons were Leiden, Legnano and Thessaloniki. The 164 sites with the shortest seasons were Reykjavik, Prague and Strasbourg (Table 1).

165 Three pollen-monitoring sites had trends towards significantly earlier start dates of the 166 Betulaceae pollen season; these were Reykjavik, Derby and Sofia (Table 1). Of these, only 167 Reykjavik, and Sofia had significantly longer seasons. Betulaceae pollen counts at Reykjavik 168 also showed a significant trend toward more intensive seasons. The only other site where 169 this occurred was Zurich.

Oleaceae pollen exposure

172 The highest exposure to pollen from the Oleaceae family, almost exclusively to Fraxinus 173 pollen, was observed in Zürich, followed by Strasbourg and Sofia (Table 2 and Fig. 2). No 174 Oleaceae pollen was detected in Reykjavik. Fraxinus pollen was also found in Madrid, but 175 Oleaceae exposure was dominated by Olea $(64 \% \pm 24 \%(S D))$. The sites with the longest 176 Oleaceae pollen seasons were Legnano, Thessaloniki and Madrid where Olea pollen is 177 recorded. The shortest Oleaceae pollen seasons were at Siauliai, Łodz, Prague and Zurich. There were no significant trends in start dates of Oleaceae pollen seasons (Table 2).

179 There was only one significant trend in the duration of Oleaceae pollen season, which was towards shorter seasons in Derby. Similarly, the only significant trend in the amount of Oleaceae recorded annually was at Madrid where seasons were becoming less intense. This did not reach significance when Olea pollen exposure was evaluated separately (slope = -

$18373.70, p=0.117)$.

Poaceae pollen exposure

Derby, Leiden and Legnano recorded the most Poaceae pollen (Table 3 and Fig.2). Whereas the pollen-monitoring sites included in this study with the lowest Poaceae pollen count were 
Reykjavik and Siauliai in the north and Thessaloniki in the south. The longest Poaceae pollen

seasons were at Legnano, Thessaloniki and Madrid. The shortest Poaceae pollen seasons were recorded at Reykjavik, Siauliai, and Łodz (Table 3).

Significant trends towards earlier Poaceae pollen seasons were recorded at Reykjavik and Strasbourg. Poaceae pollen seasons at Neustrelitz and Thessaloniki became significantly longer. Conversely, Poaceae pollen seasons at Derby were shown to be becoming significantly shorter. There were also opposite trends observed in the amount of Poaceae pollen recorded annually, with seasons becoming significantly less intense in Leiden and more intense in Legnano (Table 3).

\section{Asteraceae pollen exposure}

By far the highest Asteraceae pollen counts were recorded at Legnano, where Ambrosia pollen accounts for $90 \%$ of the total catch (Table 4 and Fig. 2). The next highest Asteraceae pollen counts were recorded at Siauliai and Prague, where Artemisia pollen dominates (mean $97 \%$ and $82 \%$ at Siauliai and Prague, respectively). The lowest Asteraceae pollen counts were at Reykjavik, Derby and Zurich. The longest Asteraceae pollen seasons were at Derby, Zurich and Madrid. Interestingly, a large proportion of Asteraceae pollen in Zurich (mean 42\%) belonged to "other Asteraceae" (not Ambrosia or Artemisia). These other Asteraceae pollen grains were airborne from April onward and extended the season. The shortest Asteraceae seasons were at Siauliai, Prague and Legnano, where either Ambrosia or Artemisia predominated.

Start dates in Asteraceae pollen seasons were shown to be getting significantly earlier at Derby (Table 4). There were no significant trends in season duration, but Asteraceae pollen seasons were becoming significantly less intense at Derby, Leiden and Strasbourg. Asteraceae pollen counts at Legnano are increasing and there is a 
213 corresponding increase in Ambrosia pollen at the site (slope=105.082; $p=0.147$ ), but the

214 trends are not significant.

215

216

DISCUSSION

217 Pollen count data are considered to be a proxy for aeroallergen exposure (15). A number of

218 studies have examined regional differences in the timing and magnitude of pollen seasons of

219 different allergenic taxa, such as Alnus (16), Betula (17, 18), Olea (19), Artemisia (20) and

220 the Poaceae family $(21,22)$. However, this is the first comprehensive study that quantifies

221 exposure, in terms of the magnitude and duration of pollen seasons across Europe over 20

222 years, for the Betulaceae, Oleaceae, Poaceae and Asteraceae families. As a consequence

223 of the cross-reactive nature of some of their major and/or minor allergens, these allergenic

224 taxa in Europe (23) have major impact on the prevalence of pollen-associated food allergies.

225 On a European scale, the greatest exposure was to allergenic pollen from the

226 Betulaceae family. This is largely due to the fact that Betulaceae pollen was the most

227 important at 9 out of the 13 sites included in this study, and mean annual Betulaceae pollen

228 counts exceeded 5000 grains at all 9 of these sites. The second most important pollen type

229 was Poaceae, which was the dominant at 3 out of the 13 sites (Reykjavik, Madrid and

230 Derby). However, in comparison to Betulaceae, mean values of $>5000$ Poaceae pollen

231 grains were only recorded at two sites (Derby and Leiden). Mean annual Oleaceae pollen

232 counts only exceeded 5000 grains at Zürich. It is interesting to note that the results of the

233 GA2LEN skin test study showed that the highest sensitization rate to olive was in Zürich

$234(45.5 \%)$, where Fraxinus is the main Oleaceae pollen in the air (mean contribution 98.6\%) (4,

235 24). In general, Asteraceae accounted for $<10 \%$ of the pollen types examined (11 out of 13

236 centres). The exceptions were Siauliai (16\% - mainly Artemisia) and Legnano (30\% - mainly

237 Ambrosia). Legnano was also the only site where mean annual Asteraceae pollen counts

238 were $>5000$ grains. It is important to note that, because of their relatively large and heavy

239 pollen grains, numbers of some pollen types like Ligustrum (Oleaceae) (25) and Artemisia 
(Asteraceae) (26) can be underestimated at roof level where monitoring stations are usually

situated. However, this is unlikely to change the overall picture of pollen exposure being dominated by Betulaceae and, to a lesser extent, by Poaceae.

In the present study, we have searched for significant changes in exposure to four major families of allergenic pollen. Developments like climate change and urbanization are expected to impact on pollen exposure (27). However, very few consistent trends were actually observed, apart from a trend towards decreased exposure to Asteraceae pollen at 8 out of 13 sites (including 3 significant trends). No consistent changes were observed in the start or duration of pollen seasons. Previous studies have shown changes in the timing of Betula pollen seasons in Europe $(17,28)$. Similar changes were also seen at Reykjavik, Derby and Sofia but these results were not consistent at all sites, possibly because such changes may be slowing or approaching a limit in some places (29). With respect to the duration of pollen seasons, it should be noted that due to the method used for defining season start and end (retrospective 95\% method), low amounts of pollen can extend the season at sites with low annual sums, therefore a direct comparison between stations with differing annual sums should be done with caution.

Overall, notable differences in exposure to the four major families of pollen have been observed. These analyses now offer the possibility to investigate the impact of these differences on the patterns of food sensitization and allergy observed in the EuroPrevall project. In a first analysis of sensitization to pollen and foods in EuroPrevall, it has clearly been demonstrated that pollen sensitization is the most dominant factor in determining sensitization to foods (30). The current study now provides the opportunity to carry out a detailed analysis of the associations between pollen exposure, food sensitization and food allergy.

\section{ACKNOWLEDGEMENTS}


266 This work was funded by the EC through the EuroPrevall project (FOOD-CT-2005-514000).

267 The authors would also like to thank the following for their expert technical assistance: Iveta 268 Lankova $^{\dagger}$, The National Institute of Public Health, Praha, Czech Republic; J. Corden and W. 269 Millington, Midlands Asthma and Allergy Research Association (MAARA), UK; A. Fairs, 270 Department of Infection, Immunity \& Inflammation, University of Leicester, UK; D. Gioulekas 271 (emeritus professor), Pulmonary Department, G.P. Hospital "G. Papanikolaou”, Aristotle 272 University of Thessaloniki, Greece. C. H. Pashley is supported by the Midlands Asthma and 273 Allergy Research Association (MAARA) and the National Institute for Health Research 274 Leicester Respiratory Biomedical Research Unit and the views expressed are those of the 275 author(s) and not necessarily those of the NHS, the NIHR or the Department of Health.

276 Authors Contribution to the work:

277 The project outline was drafted by RvR, MS, SJ, UB and KHS. The data acquisition and 278 coordination of pollen sets was performed by BS, MS SJ, and UB. Finally all the authors MS, 279 SJ, UB, BS, MH, IS, KB, CHP, LW, BMW, OR, MT, RG, MB, RY, AD, DV, AMGB, KHS and 280 RvR provided substantial contributions to conception and design of the study, acquired data 281 or analysed and interpreted data. Subsequently they all provided input to drafting the article 282 and revising it critically for important intellectual content and gave final approval of the 283 version to be published.

284 Conflict of Interest:

285 None of the authors declared a conflict of interest in relation to the current manuscript.

286

287 FIGURE LEGENDS

288 Fig. 1. Location of EuroPrevall allergy centres and pollen-monitoring sites 289 
290 Fig. 2 Pollen exposure across Europe. The size of each circle represents the mean 291 exposure level to all four pollen families (Betulaceae, Oleaceae, Poaceae and Asteraceae) 292 together (mean yearly sum of daily pollen concentrations shown in parenthesis) in the 293 thirteen centres across Europe, ranging from 2,565 in Thessaloniki to 28,177 in Zurich. The 294 pie charts illustrate the relative importance (\% indicated) of each of the four main families of 295 allergenic pollen per centre.

296

297

REFERENCES

298

299

1. Burks AW, Tang M, Sicherer S, Muraro A, Eigenmann PA, Ebisawa M, et al. ICON:

300 Food allergy. J Allergy Clin Immunol 2012;129(4):906-920.

301

2. Chapman JA, Bernstein I, Lee RE, Oppenheimer J, Nicklas RA, Portnoy JM, et al.

302

303

304

305

306

307

308

309

310

311

312 Food allergy: a practice parameter. Ann Allergy Asthma Immunol 2006;96(3, Suppl. 2).

3. Lombardero M, García-Sellés FJ, Polo F, Jimeno L, Chamorro MJ, García-Casado G, et al. Prevalence of sensitization to Artemisia allergens Art v 1, Art v 3 and Art v 60 kDa.

Cross-reactivity among Art v 3 and other relevant lipid-transfer protein allergens. Clin Exp Allergy 2004;34(9):1415-1421.

4. Heinzerling LM, Burbach GJ, Edenharter G, Bachert C, Bindslev-Jensen C, Bonini S, et al. GA2LEN skin test study I: GA²LEN harmonization of skin prick testing: novel sensitization patterns for inhalant allergens in Europe. Allergy 2009;64(10):1498-1506.

5. Mills ENC, Mackie AR, Burney P, Beyer K, Frewer L, Madsen C, et al. The prevalence, cost and basis of food allergy across Europe. Allergy 2007;62(7):717-722.

313 EuroPrevall birth cohort study on food allergy: baseline characteristics of 12,000 newborns

314 and their families from nine European countries. Ped Allergy Immunol 2012;23(3):230-239. 
315 7. Kummeling I, Mills ENC, Clausen M, Dubakiene R, Pérez CF, Fernández-Rivas M, et

316 al. The EuroPrevall surveys on the prevalence of food allergies in children and adults:

317 background and study methodology. Allergy 2009;64(10):1493-1497.

318 8. Fernández-Rivas M, Bolhaar S, González-Mancebo E, Asero R, van Leeuwen A,

319 Bohle B, et al. Apple allergy across Europe: How allergen sensitization profiles determine the 320 clinical expression of allergies to plant foods. J Allergy Clin Immunol 2006;118(2):481-488.

321 9. Skamstrup Hansen K, Ballmer-Weber BK, Sastre J, Lidholm J, Andersson K,

322 Oberhofer $\mathrm{H}$, et al. Component-resolved in vitro diagnosis of hazelnut allergy in Europe. $J$

323 Allergy Clin Immunol 2009;123(5):1134-1141.e1133.

324 10. Pastor C, Cuesta-Herranz J, Cases B, Pérez-Gordo M, Figueredo E, de las Heras M, 325 et al. Identification of Major Allergens in Watermelon. Int Arch Allergy Immunol

$3262009 ; 149(4): 291-298$.

327 11. Hirst JM. An automatic volumetric spore trap. Ann Appl Biol 1952;39(2):257-265.

328 12. Cariñanos P, Emberlin J, Galán C, Dominguez Vilches E. Comparison of two pollen

329 counting methods of slides from a Hirst type volumetric trap. Aerobiologia 2000;16(3/4):339-

330346.

331 13. Goldberg C, Buch H, Moseholm L, Weeke EV. Airborne pollen records in Denmark, 332 1977-1986. Grana 1988;27:209-217.

333 14. APGIII. An update of the Angiosperm Phylogeny Group classification for the orders 334 and families of flowering plants: APG III. Bot J Linn Soc 2009;161:105-121.

335 15. Buters JTM, Thibaudon M, Smith M, Kennedy R, Rantio-Lehtimäki A, Albertini R, et 336 al. Release of Bet $v 1$ from birch pollen from 5 European countries. Results from the 337 HIALINE study. Atmos Environ 2012;55:496-505.

338 16. Smith M, Emberlin J, Stach A, Czarnecka-Operacz M, Jenerowicz D, Silny W. The 339 regional importance of Alnus pollen as an aeroallergen: A comparative study of Alnus pollen 340 counts from Worcester (UK) and Poznań (Poland). Ann Agric Environ Med 2007(14):123341128. 
342 17. Emberlin J, Detandt M, Gehrig R, Jaeger S, Nolard N, Rantio-Lehtimäki A.

343 Responses in the start of Betula (birch) pollen seasons to recent changes in spring

344 temperatures across Europe. Int J Biometeorol 2002;46:159-170.

345 18. Stach A, Emberlin J, Smith M, Adams-Groom B, Myszkowska D. Factors that

346 determine the severity of Betula spp. pollen seasons in Poland (Poznań and Krakow) and the

347 United Kingdom (Worcester and London). Int J Biometeorol 2008;52(4):311-321.

348 19. Díaz de la Guardia C, Alba F, Del Mar Trigo M, Galán C, Ruíz L, Sabariego S.

349 Aerobiological analysis of Olea europaea L. pollen in different localities of southern Spain.

350 Grana 2003;42(4):234-243.

351 20. Grewling Ł, Šikoparija B, Skjøth CA, Radišić $P$, Apatini D, Magyar D, et al. Variation

352 in Artemisia pollen seasons in Central and Eastern Europe. Agric For Meteorol

$353 \quad 2012 ; 160(0): 48-59$.

354 21. Emberlin J, Jaeger S, Dominguez Vilches E, Galan Soldevilla C, Hodal L, Mandrioli P, 355 et al. Temporal and geographical variations in grass pollen seasons in areas of western

356 Europe: and analysis of season dates at sites of the European pollen information system.

357 Aerobiologia 2000;16:373-379.

358 22. Smith M, Emberlin J, Stach A, Rantio-Lehtimäki A, Caulton E, Thibaudon M, et al.

359 Influence of the North Atlantic Oscillation on grass pollen counts in Europe. Aerobiologia

$360 \quad 2009 ; 25(4): 321-332$.

361 23. Skjøth CA, Šikoparija B, Jäger S, EAN. Pollen Sources. In: Sofiev M, Bergmann K-C, 362 editors. Allergenic Pollen: Springer Netherlands; 2013. p. 9-27.

363 24. Burbach GJ, Heinzerling LM, Edenharter G, Bachert C, Bindslev-Jensen C, Bonini S, 364 et al. GA2LEN skin test study II: clinical relevance of inhalant allergen sensitizations in 365 Europe. Allergy 2009;64(10):1507-1515.

366 25. Cariñanos P, Alcázar P, Galán C, Domínguez E. Privet pollen (Ligustrum sp.) as 367 potential cause of pollinosis in the city of Cordoba, south-west Spain. Allergy 2002;57(2):9236897. 
369 26. Spieksma FT, van Noort P, Nikkels H. Influence of nearby stands of Artemisia on

370 street-level versus roof-top-level ratio's of airborne pollen quantities. Aerobiologia

$3712000 ; 16: 21-24$.

372 27. Ziello C, Sparks TH, Estrella N, Belmonte J, Bergmann KC, Bucher E, et al. Changes

373 to airborne pollen counts across europe. PLoS ONE 2012;7(4): e34076.

374 doi:34010.31371/journal.pone.0034076.

375 28. Emberlin J, Mullins J, Cordon J, Millington W, Brooke M, Savage M, et al. The trend

376 to earlier birch pollen seasons in the UK: a biotic response to changes in weather conditions?

377 Grana 1997;36: 29-33.

378 29. Newnham RM, Sparks TH, Skjøth CA, Head K, Adams-Groom B, Smith M. Pollen

379 season and climate: Is the timing of birch pollen release in the UK approaching its limit? Int $J$

380 Biometeorol 2012;57(3):391-400.

381 30. Burney PGJ, Potts J, Kummeling I, Mills ENC, Clausen M, Dubakiene R, et al. The

382 prevalence and distribution of food sensitization in European adults. Allergy 2013:doi:

$383 \quad 10.1111 / a l l .12341$.

384 
Table 1. Start dates, intensity (sum of pollen recorded in the season) and duration of Betulaceae pollen seasons recorded at 13 pollen-monitoring stations included in this study. The following statistics are included: the mean, Standard Deviation (SD), slope of the regression over time, Standard Error of the regression slope (SE), probability level $(p)$ and number of years in the analysis (N).

\begin{tabular}{|c|c|c|c|c|c|c|c|c|c|c|c|c|c|c|c|c|c|c|c|c|c|}
\hline \multirow{2}{*}{$\begin{array}{c}\text { Pollen- } \\
\text { monitoring } \\
\text { station }\end{array}$} & \multirow[t]{2}{*}{ Pollen types } & \multicolumn{6}{|c|}{ Start (DOY) } & \multicolumn{6}{|c|}{ Sum Year (grains) } & \multicolumn{6}{|c|}{ Duration (days) } & \multicolumn{2}{|c|}{$\begin{array}{c}\text { Most dominant } \\
\text { taxa }\end{array}$} \\
\hline & & Mean & SD & Slope & $\mathrm{SE}$ & $p$ & $\mathrm{~N}$ & Mean & SD & Slope & SE & $p$ & $\mathrm{~N}$ & Mean & SD & Slope & $\mathrm{SE}$ & $p$ & $\mathrm{~N}$ & Taxa & $\begin{array}{l}\text { Mean } \\
\%\end{array}$ \\
\hline Reykjavik $^{1}$ & $a, b$ & 142 & 8.2 & -1.0 & 0.2 & 0.000 & 20 & 512 & 545 & 46.6 & 18.7 & 0.023 & 20 & 38 & 13.8 & 1.1 & 0.5 & 0.034 & 20 & $\mathrm{~b}$ & 100 \\
\hline Siauliai & $a, b, c, d$ & 78 & - & - & - & - & 6 & 8973 & - & - & - & - & 6 & 63 & - & - & - & - & 6 & $\mathrm{~b}$ & 73 \\
\hline Neustrelitz & $a, b, c, d$ & 53 & 20.6 & -0.2 & 1.1 & 0.878 & 16 & 9870 & 5846 & -240.8 & 292.4 & 0.423 & 17 & 75 & 19.7 & -0.1 & 1.0 & 0.925 & 16 & $b$ & 58 \\
\hline Derby & $a, b, c, d$ & 49 & 18.0 & -1.8 & 0.6 & 0.005 & 19 & 3622 & 2313 & 116.0 & 89.5 & 0.212 & 19 & 83 & 12.5 & -0.4 & 0.5 & 0.393 & 19 & $\mathrm{~b}$ & 68 \\
\hline Leiden & $a, b, c, d$ & 35 & 19.5 & -1.0 & 0.8 & 0.235 & 19 & 7865 & 3464 & -187.5 & 130.7 & 0.169 & 20 & 102 & 41.7 & 0.3 & 1.8 & 0.846 & 19 & $a$ & 49 \\
\hline Łodz & $a, b, c, d$ & 67 & - & - & - & - & 4 & 17325 & - & - & - & - & 4 & 59 & - & - & - & - & 4 & $\mathrm{~b}$ & 79 \\
\hline Prague $^{2}$ & $a, b, c, d, e$ & 72 & - & - & - & - & 7 & 10821 & 5241 & 44.7 & 283.7 & 0.877 & 15 & 52 & - & - & - & - & 7 & $\mathrm{~b}$ & 84 \\
\hline Strasbourg $^{2}$ & $a, b, c, d$ & 56 & - & - & - & - & 6 & 9281 & 5222 & 141.5 & 217.2 & 0.525 & 17 & 79 & - & - & - & - & 6 & $\mathrm{~b}$ & 50 \\
\hline Zürich & $a, b, c, d, e$ & 39 & 20.3 & 0.1 & 0.8 & 0.921 & 20 & 14921 & 4948 & 454.1 & 165.6 & 0.013 & 20 & 87 & 18.4 & 0.1 & 0.7 & 0.852 & 20 & $\mathrm{~b}$ & 66 \\
\hline Legnano $^{3}$ & $a, b, c, d, e, f, g$ & 41 & 9.3 & -0.1 & 0.6 & 0.824 & 14 & 8311 & 4498 & 470.6 & 246.6 & 0.079 & 15 & 107 & 19.6 & -0.8 & 1.2 & 0.502 & 14 & $f$ & 67 \\
\hline Sofia & $a, b, c, d$ & 71 & 24.8 & -5.7 & 1.2 & 0.001 & 11 & 5904 & 2021 & 165.5 & 174.0 & 0.366 & 11 & 56 & 25.6 & 6.0 & 1.2 & 0.001 & 11 & $\mathrm{~b}$ & 74 \\
\hline Thessaloniki & $a, b, c, d$ & 48 & 8.2 & -0.0 & 0.3 & 0.989 & 20 & 533 & 357 & 26.5 & 12.8 & 0.053 & 20 & 97 & 12.8 & -0.6 & 0.5 & 0.237 & 20 & $\begin{array}{l}\text { c } \\
d\end{array}$ & $\begin{array}{l}40 \\
41 \\
\end{array}$ \\
\hline Madrid $^{4}$ & $a, b, d$ & - & - & - & - & - & - & 169 & 99 & -1.16 & 5.6 & 0.839 & 15 & - & - & - & - & - & - & $\mathrm{a}$ & 62 \\
\hline
\end{tabular}

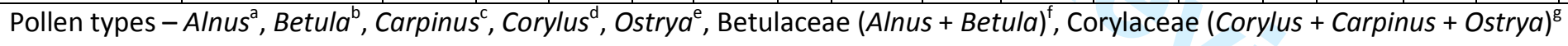

${ }^{1}$ The majority of Betulaceae pollen recorded at Reykjavik was from Betula (99.8\%) and only a small amount of Alnus pollen was registered.

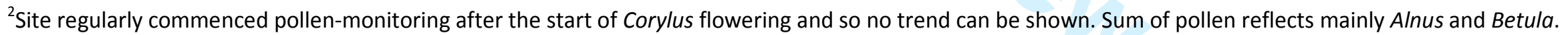

${ }^{3}$ Legnano changed from simply recording Betulaceae and Corylaceae pollen to recording Alnus, Betula, Carpinus, Corylus and Ostrya pollen in 2009.

${ }^{4}$ Betulaceae pollen counts at Madrid are intermittent and highly variable (from 33 to 356 grains in a year), it was therefore not possible to calculate start and end of the season. 
Table 2. Start dates, intensity (sum of pollen recorded in the season) and duration of Oleaceae pollen seasons recorded at 13 pollen-monitoring stations included in this study. The following statistics are included: the mean, Standard Deviation (SD), slope of the regression over time, Standard Error of the regression slope (SE), probability level $(p)$ and number of years in the analysis (N).

\begin{tabular}{|c|c|c|c|c|c|c|c|c|c|c|c|c|c|c|c|c|c|c|c|c|c|}
\hline \multirow[t]{2}{*}{$\begin{array}{c}\text { Pollen-monitoring } \\
\text { station }\end{array}$} & \multirow[t]{2}{*}{$\begin{array}{c}\text { Pollen } \\
\text { types }\end{array}$} & \multicolumn{6}{|c|}{ Start (DOY) } & \multicolumn{6}{|c|}{ Sum Year (grains) } & \multicolumn{6}{|c|}{ Duration (days) } & \multicolumn{2}{|c|}{$\begin{array}{c}\text { Most dominant } \\
\text { taxa }\end{array}$} \\
\hline & & Mean & SD & Slope & $\mathrm{SE}$ & $p$ & $\mathrm{~N}$ & Mean & SD & Slope & SE & $p$ & $N$ & Mean & SD & Slope & $\mathrm{SE}$ & $p$ & $\mathrm{~N}$ & Taxa & Mean \% \\
\hline Reykjavik $^{1}$ & NA & - & - & - & - & - & - & - & - & - & - & - & - & - & - & - & - & - & - & - & - \\
\hline Siauliai & $\mathrm{i}$ & 113 & - & - & - & - & 5 & 200 & - & - & - & - & 5 & 32 & - & - & - & - & 5 & $\mathrm{i}$ & 100 \\
\hline Neustrelitz & $h, i, j$, & 95 & 9.9 & -0.3 & 0.5 & 0.604 & 16 & 348 & 233 & 5.8 & 11.8 & 0.631 & 16 & 40 & 26.4 & -1.2 & 1.3 & 0.374 & 16 & $\mathrm{i}$ & 99 \\
\hline Derby & $h, i, j, n$ & 83 & 16.0 & 0.4 & 0.6 & 0.525 & 20 & 913 & 681 & 31.7 & 26.1 & 0.240 & 20 & 57 & 33.1 & -3.4 & 1.0 & 0.004 & 20 & $\mathrm{i}$ & 94 \\
\hline Leiden & $h, i, j$ & 81 & 15.6 & 0.7 & 0.6 & 0.296 & 19 & 1300 & 922 & -7.6 & 36.9 & 0.840 & 19 & 67 & 41.4 & -2.1 & 1.6 & 0.201 & 19 & $\mathrm{i}$ & 96 \\
\hline Łodz & $\mathrm{i}$ & 103 & - & - & - & - & 4 & 990 & - & - & - & - & 4 & 34 & - & - & - & - & 4 & $i$ & 100 \\
\hline Prague & $i, j$, & 89 & 11.5 & 0.2 & 0.6 & 0.737 & 15 & 1543 & 926 & -12.9 & 50.0 & 0.801 & 15 & 35 & 20.7 & -1.6 & 1.0 & 0.142 & 15 & $\mathrm{i}$ & 99 \\
\hline Strasbourg & $h, i, j$, & 75 & 14.4 & 0.3 & 0.7 & 0.669 & 15 & 2250 & 1268 & 24.7 & 54.3 & 0.656 & 17 & 48 & 25.1 & -0.5 & 1.3 & 0.696 & 15 & $\mathrm{i}$ & 99 \\
\hline Zurich $^{2}$ & $\mathrm{i}, \mathrm{m}$ & 86 & 10.7 & 0.2 & 0.4 & 0.659 & 19 & 5750 & 3261 & 42.5 & 135.9 & 0.759 & 19 & 35 & 13.6 & -0.1 & 0.6 & 0.875 & 19 & $\mathrm{i}$ & 99 \\
\hline Legnano & $i, j, k, l, m$ & 76 & 12.9 & -0.7 & 0.8 & 0.413 & 15 & 1065 & 894 & 82.4 & 50.5 & 0.127 & 15 & 94 & 17.4 & 0.1 & 1.1 & 0.953 & 15 & 1 & 100 \\
\hline Sofia & $i, j$, & 77 & 15.3 & -1.1 & 1.0 & 0.275 & 12 & 2036 & 1408 & 65.5 & 86.8 & 0.466 & 13 & 41 & 14.1 & 0.6 & 0.9 & 0.530 & 12 & $\mathrm{i}$ & 99 \\
\hline Thessaloniki & $\mathrm{k}$ & 94 & 12.7 & -0.2 & 0.5 & 0.752 & 20 & 853 & 407 & 20.0 & 15.5 & 0.214 & 20 & 78 & 15.3 & 0.0 & 0.6 & 0.951 & 20 & $\mathrm{k}$ & 100 \\
\hline Madrid & $\mathrm{i}, \mathrm{j}, \mathrm{k}$ & 20 & 9.5 & 0.3 & 0.7 & 0.668 & 13 & 1870 & 815 & \begin{tabular}{|l|}
-113.2 \\
\end{tabular} & 39.9 & 0.015 & 14 & 158 & 19.2 & -0.3 & 1.3 & 0.826 & 13 & $\mathrm{k}$ & 64 \\
\hline
\end{tabular}

Pollen types - Forsythia ${ }^{\mathrm{h}}$, Fraxinus $^{\mathrm{i}}$, Ligustrum $^{\mathrm{j}}$, Olea $^{\mathrm{k}}$, Oleaceae $^{\mathrm{l}}$, other Oleaceae ${ }^{\mathrm{m}}$, Syringa $^{\mathrm{n}}$

${ }^{1}$ No Oleaceae pollen recorded at Reykjavik

${ }^{2}$ Note that only Fraxinus excelsior pollen grains are recorded as "Fraxinus" pollen in Zurich. Low amounts of Fraxinus ornus pollen are also seen in the samples, but these are recorded as "other Oleaceae". 


\section{Page 35 of 42}

Allergy

Table 3. Start dates, intensity (sum of pollen recorded in the season) and duration of Poaceae pollen seasons recorded at 13 pollen-monitoring stations included in this study. The following statistics are included: the mean, Standard Deviation (SD), slope of the regression over time, Standard Error of the regression slope (SE), probability level $(p)$ and number of years in the analysis (N).

\begin{tabular}{|c|c|c|c|c|c|c|c|c|c|c|c|c|c|c|c|c|c|c|c|c|c|}
\hline \multirow[t]{2}{*}{$\begin{array}{l}\text { Pollen-monitoring } \\
\text { station }\end{array}$} & \multirow[t]{2}{*}{$\begin{array}{l}\text { Pollen } \\
\text { types }\end{array}$} & \multicolumn{6}{|c|}{ Start (DOY) } & \multicolumn{6}{|c|}{ Sum Year (grains) } & \multicolumn{6}{|c|}{ Duration (days) } & \multicolumn{2}{|c|}{$\begin{array}{l}\text { Most dominant } \\
\text { taxa }\end{array}$} \\
\hline & & Mean & SD & Slope & SE & $p$ & $\mathrm{~N}$ & Mean & SD & Slope & SE & $p$ & $\mathrm{~N}$ & Mean & SD & Slope & SE & $p$ & $\mathrm{~N}$ & Taxa & Mean \% \\
\hline Reykjavik & $p$ & 174 & 6.0 & -0.5 & 0.2 & 0.020 & 20 & 1747 & 707 & 35.6 & 26.9 & 0.202 & 20 & 69 & 9.4 & -0.4 & 0.4 & 0.254 & 20 & $p$ & 100 \\
\hline Siauliai & $p, q$ & 158 & - & - & - & - & 6 & 2007 & - & - & - & - & 6 & 83 & - & - & - & - & 6 & $p$ & 99 \\
\hline Neustrelitz & $p, q, r$ & 142 & 9.6 & -0.7 & 0.4 & 0.141 & 14 & 3100 & 1059 & -52.2 & 47.8 & 0.291 & 18 & 93 & 20.6 & 2.7 & 0.7 & 0.001 & 14 & $p$ & 97 \\
\hline Derby & $p$ & 145 & 10.6 & 0.1 & 0.4 & 0.841 & 20 & 5467 & 1995 & 85.3 & 76.9 & 0.282 & 20 & 91 & 19.5 & -2.2 & 0.6 & 0.002 & 20 & $p$ & 100 \\
\hline Leiden & $p$ & 133 & 9.7 & -0.5 & 0.4 & 0.220 & 20 & 5122 & 1898 & -231.8 & 52.3 & 0.000 & 20 & 118 & 10.5 & 0.4 & 0.4 & 0.305 & 20 & $p$ & 100 \\
\hline Łodz $^{1}$ & $o, p, q$ & 142 & - & - & - & - & 2 & 3874 & - & - & - & 0.681 & 5 & 82 & - & - & - & - & 2 & $p$ & 95 \\
\hline Prague & $p, q, r$ & 136 & 6.7 & -0.7 & 0.4 & 0.138 & 13 & 2946 & 1758 & -211.6 & 101.3 & 0.061 & 13 & 92 & 17.2 & 0.3 & 1.2 & 0.822 & 13 & $p$ & 98 \\
\hline Strasbourg & $p$ & 130 & 7.7 & -0.9 & 0.3 & 0.021 & 11 & 2942 & 1145 & -40.8 & 48.7 & 0.414 & 18 & 94 & 19.5 & -1.3 & 1.0 & 0.221 & 11 & $p$ & 100 \\
\hline Zürich & $p, q$ & 133 & 5.7 & -0.2 & 0.2 & 0.290 & 20 & 3753 & 788 & 51.6 & 28.9 & 0.091 & 20 & 96 & 10.6 & -0.1 & 0.4 & 0.793 & 20 & $p$ & 100 \\
\hline Legnano & $p$ & 105 & 7.6 & -0.2 & 0.5 & 0.650 & 15 & 4250 & 1551 & 182.1 & 81.9 & 0.044 & 15 & 148 & 13.7 & 0.3 & 0.8 & 0.736 & 15 & $p$ & 100 \\
\hline Sofia & $p$ & 126 & 11.6 & 0.1 & 0.6 & 0.874 & 16 & 3736 & 1601 & \begin{tabular}{|l|}
-101.8 \\
\end{tabular} & 64.9 & 0.136 & 18 & 114 & 16.1 & 1.0 & 0.7 & 0.183 & 16 & $p$ & 100 \\
\hline Thessaloniki & $p$ & 98 & 16.1 & 0.0 & 0.6 & 0.998 & 20 & 591 & 339 & 24.3 & 12.2 & 0.063 & 20 & 152 & 38.7 & 3.0 & 1.4 & 0.045 & 20 & $p$ & 100 \\
\hline Madrid $^{1}$ & $p$ & 58 & - & - & - & - & 4 & 3141 & 2123 & -95.9 & 126.1 & 0.464 & 12 & 211 & - & - & - & - & 4 & $p$ & 100 \\
\hline
\end{tabular}

Pollen types - Cerealia ${ }^{\circ}$, Poaceae ${ }^{p}$, Secale ${ }^{q}$, Zea mays $^{r}$

${ }^{1}$ Monitoring station did not operate continuously and so it was not always possible to calculate start and end of the season. However, it was still possible to calculate intensity. 
Table 4. Start dates, intensity (sum of pollen recorded in the season) and duration of Asteraceae pollen seasons recorded at 13 pollen-monitoring stations included in this study. The following statistics are included: the mean, Standard Deviation (SD), slope of the regression over time, Standard Error of the regression slope (SE), probability level ( $p$ ) and number of years in the analysis (N).

\begin{tabular}{|c|c|c|c|c|c|c|c|c|c|c|c|c|c|c|c|c|c|c|c|c|c|}
\hline \multirow[t]{2}{*}{$\begin{array}{l}\text { Pollen-monitoring } \\
\text { station }\end{array}$} & \multirow[t]{2}{*}{$\begin{array}{l}\text { Pollen } \\
\text { types }\end{array}$} & \multicolumn{6}{|c|}{ Start (DOY) } & \multicolumn{6}{|c|}{ Sum Year (grains) } & \multicolumn{6}{|c|}{ Duration (days) } & \multicolumn{2}{|c|}{$\begin{array}{l}\text { Most dominant } \\
\text { taxa }\end{array}$} \\
\hline & & Mean & SD & Slope & $\mathrm{SE}$ & $p$ & $\mathrm{~N}$ & Mean & SD & Slope & SE & $p$ & $\mathrm{~N}$ & Mean & SD & Slope & SE & $p$ & $\mathrm{~N}$ & Taxa & Mean \% \\
\hline Reykjavik $^{1}$ & $t, u, v, x$ & 161 & - & - & - & - & 5 & 54 & - & - & - & - & 5 & 90 & - & - & - & - & 5 & $v+x$ & 92 \\
\hline Siauliai & $\mathrm{s}, \mathrm{t}, \mathrm{u}$ & 202 & - & - & - & - & 7 & 2168 & - & - & - & - & 7 & 40 & - & - & - & - & 7 & $\mathrm{t}$ & 97 \\
\hline Neustrelitz & $s, t, u, v$ & 181 & 22.0 & 0.2 & 1.1 & 0.830 & 15 & 777 & 261 & -17.2 & 12.0 & 0.174 & 15 & 67 & 27.1 & 1.6 & 1.3 & 0.222 & 15 & $\mathrm{t}$ & 88 \\
\hline Derby & $\mathrm{s}, \mathrm{t}, \mathrm{x}$ & 153 & 33.9 & -3.4 & 1.1 & 0.005 & 20 & 80 & 42 & -3.6 & 1.5 & 0.022 & 20 & 115 & 43.0 & 1.3 & 1.7 & 0.440 & 20 & $\mathrm{t}$ & 97 \\
\hline Leiden & $s, t, u$ & 167 & 28.8 & -0.2 & 1.1 & 0.850 & 20 & 491 & 320 & -46.6 & 6.1 & 0.000 & 19 & 84 & 29.3 & 0.7 & 1.2 & 0.545 & 20 & $\mathrm{t}$ & 87 \\
\hline Łodz $^{1}$ & $s, t$ & 191 & - & - & - & - & 3 & 994 & - & - & - & - & 3 & 64 & - & - & - & - & 3 & $\mathrm{t}$ & 85 \\
\hline Prague & $s, t, u, v$ & 197 & 13.1 & 0.9 & 0.7 & 0.229 & 15 & 1534 & 1126 & -107.6 & 54.7 & 0.069 & 16 & 60 & 17.0 & -0.9 & 1.0 & 0.387 & 15 & $\mathrm{t}$ & 82 \\
\hline Strasbourg & $\mathrm{s}, \mathrm{t}, \mathrm{u}, \mathrm{v}$ & 147 & 29.2 & -0.7 & 1.2 & 0.568 & 19 & 237 & 112 & -12.8 & 3.3 & 0.001 & 19 & 105 & 32.5 & 0.5 & 1.3 & 0.685 & 19 & $\mathrm{t}$ & 74 \\
\hline Zürich & $s, t, u$ & 122 & 17.4 & -0.5 & 0.7 & 0.452 & 20 & 82 & 35 & 1.1 & 1.4 & 0.418 & 20 & 138 & 18.4 & 0.9 & 0.7 & 0.199 & 20 & $\begin{array}{l}\mathrm{u} \\
\mathrm{t}\end{array}$ & $\begin{array}{l}42 \\
33\end{array}$ \\
\hline Legnano & $s, t, u$ & 219 & 3.6 & -0.2 & 0.2 & 0.441 & 15 & 5393 & 1224 & 71.7 & 73.3 & 0.346 & 15 & 53 & 7.4 & 0.1 & 0.5 & 0.783 & 15 & $\mathrm{~s}$ & 90 \\
\hline Sofia & $s, t, u, v$ & 188 & 13.4 & 0.3 & 1.0 & 0.744 & 13 & 1281 & 416 & -29.3 & 31.0 & 0.365 & 13 & 78 & 15.7 & 0.5 & 1.2 & 0.713 & 13 & $\begin{array}{l}s \\
t\end{array}$ & $\begin{array}{l}42 \\
54\end{array}$ \\
\hline Thessaloniki & $s, t, u, v$ & 124 & 35.5 & 0.2 & 1.5 & 0.919 & 19 & 148 & 63 & -1.3 & 2.7 & 0.636 & 19 & 152 & 39.3 & 0.3 & 1.7 & 0.881 & 19 & $\begin{array}{l}\mathrm{s} \\
\mathrm{t}\end{array}$ & $\begin{array}{l}45 \\
36\end{array}$ \\
\hline Madrid $^{1}$ & $t, w$ & 92 & 50.3 & -3.5 & 2.8 & 0.227 & 15 & 160 & 130 & -13.1 & 6.7 & 0.070 & 15 & 196 & 67.3 & 0.7 & 3.9 & 0.868 & 15 & $w$ & 70 \\
\hline
\end{tabular}

Pollen types - Ambrosia ${ }^{\mathrm{s}}$, Artemisia $^{\mathrm{t}}$, Asteraceae ${ }^{\mathrm{u}}$, Cichoriaceae ${ }^{\mathrm{v}}$, Compositae (Asteraceae) $^{\mathrm{w}}$, , $^{\text {(araxacum }}{ }^{\mathrm{x}}$

${ }^{1}$ Reykjavik - Asteraceae pollen were only recorded from 2005 to 2009 . Cichoriaceae and Taraxacum were counted separately in 2005 and 2009 . However, in other years only Taraxacum was counted. Therefore Cichoriaceae and Taraxacum have been combined to produce the most dominant taxa (2005-2009). 
Fig. 1. Location of EuroPrevall allergy centres and pollen-monitoring sites

\section{EuroPrevall allergy centre}

Location of pollen-monitoring site

Latitude Longitude
Height above sea level (m)

\begin{tabular}{lllccc}
\hline Reykjavik (IS) & Reykjavik & $64^{\circ} 07^{\prime} \mathrm{N}$ & $21^{\circ} 54^{\prime} \mathrm{W}$ & 52 & $1990-2009$ \\
Vilnius (LT) & Siauliai & $55^{\circ} 55^{\prime} \mathrm{N}$ & $23^{\circ} 18^{\prime} \mathrm{E}$ & 128 & $2003-2009$ \\
\hline Berlin (DE) & Neustrelitz & $53^{\circ} 22^{\prime} \mathrm{N}$ & $13^{\circ} 05^{\prime} \mathrm{E}$ & 70 & $1992-2009$ \\
\hline Manchester & Derby & $52^{\circ} 55^{\prime} \mathrm{N}$ & $01^{\circ} 30^{\prime} \mathrm{W}$ & 78 & $1990-2009$
\end{tabular}

(GB)

\begin{tabular}{llllll}
\hline Leiden (NL) & Leiden & $52^{\circ} 09^{\prime} \mathrm{N}$ & $04^{\circ} 28^{\prime} \mathrm{E}$ & -1 & $1990-2009$ \\
\hline Łodz (PL) & Łodz & $51^{\circ} 45^{\prime} \mathrm{N}$ & $19^{\circ} 27^{\prime} \mathrm{E}$ & 187 & $2005-2009$ \\
\hline Prague (CZ) & Prague & $50^{\circ} 05^{\prime} \mathrm{N}$ & $14^{\circ} 25^{\prime} \mathrm{E}$ & 245 & $1993-2009$ \\
\hline $\begin{array}{l}\text { Strasbourg } \\
\text { (FR) }\end{array}$ & Strasbourg & $48^{\circ} 34^{\prime} \mathrm{N}$ & $07^{\circ} 44^{\prime} \mathrm{E}$ & 142 & $1990-2009$ \\
\hline Zurich (CH) & Zurich & $47^{\circ} 23^{\prime} \mathrm{N}$ & $08^{\circ} 33^{\prime} \mathrm{E}$ & 556 & $1990-2009$ \\
\hline Milan (IT) & Legnano & $45^{\circ} 35^{\prime} \mathrm{N}$ & $08^{\circ} 55^{\prime} \mathrm{E}$ & 219 & $1995-2009$ \\
\hline Sofia (BG) & Sofia & $42^{\circ} 42^{\prime} \mathrm{N}$ & $23^{\circ} 17^{\prime} \mathrm{E}$ & 586 & $1991-2009$ \\
\hline Athens (GR) & Thessaloniki & $40^{\circ} 38^{\prime} \mathrm{N}$ & $22^{\circ} 57^{\prime} \mathrm{E}$ & 24 & $1990-2009$ \\
\hline Madrid (ES) & Madrid & $40^{\circ} 25^{\prime} \mathrm{N}$ & $03^{\circ} 43^{\prime} \mathrm{W}$ & 615 & $1994-2009$ \\
\hline
\end{tabular}

IS - Iceland; LT - Lithuania; DE - Germany; NL - The Netherlands; PL - Poland; CZ -

Czech Republic; FR - France; CH - Switzerland; IT - Italy; BG - Bulgaria; GR - Greece; ES - Spain. 
Fig. 2 Pollen exposure across Europe. The size of each circle represents the mean exposure level to all four pollen families (Betulaceae, Oleaceae, Poaceae and Asteraceae) together (mean yearly sum of daily pollen concentrations shown in parenthesis) in the thirteen centres across Europe, ranging from 2,565 in Thessaloniki to 28,177 in Zurich. The pie charts illustrate the relative importance (\% indicated) of each of the four main families of allergenic pollen per centre.

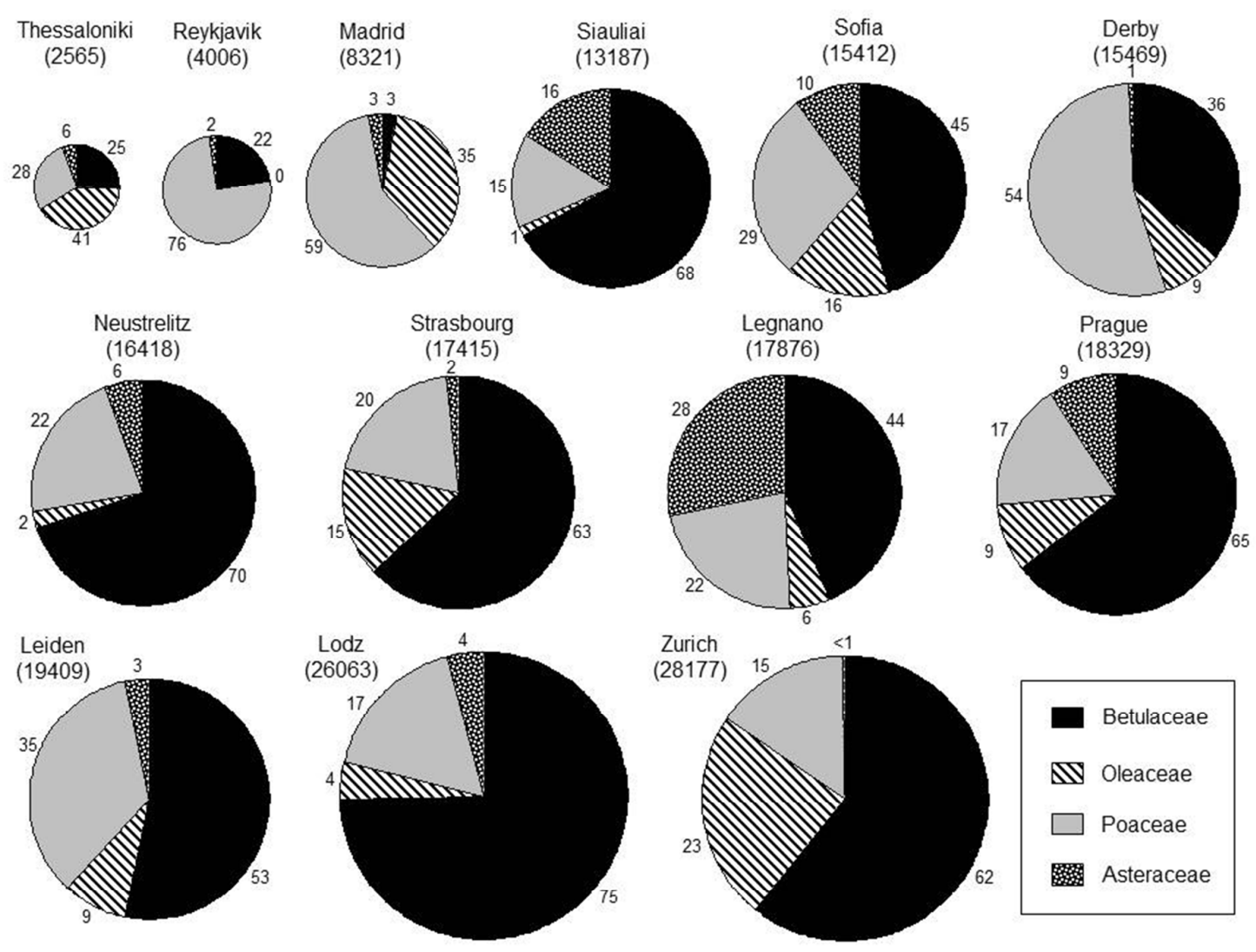


Table 1. Start dates, intensity (sum of pollen recorded in the season) and duration of Betulaceae pollen seasons recorded at 13 pollen-monitoring stations included in this study. The following statistics are included: the mean, Standard Deviation (SD), slope of the regression over time, Standard Error of the regression slope (SE), probability level $(p)$ and number of years in the analysis (N).

\begin{tabular}{|c|c|c|c|c|c|c|c|c|c|c|c|c|c|c|c|c|c|c|c|c|c|}
\hline \multirow{2}{*}{$\begin{array}{c}\text { Pollen- } \\
\text { monitoring } \\
\text { station }\end{array}$} & \multirow[t]{2}{*}{ Pollen types } & \multicolumn{6}{|c|}{ Start (DOY) } & \multicolumn{6}{|c|}{ Sum Year (grains) } & \multicolumn{6}{|c|}{ Duration (days) } & \multicolumn{2}{|c|}{$\begin{array}{c}\text { Most dominant } \\
\text { taxa }\end{array}$} \\
\hline & & Mean & SD & Slope & SE & $p$ & $\mathrm{~N}$ & Mean & SD & Slope & SE & $p$ & $\mathrm{~N}$ & Mean & SD & Slope & $\mathrm{SE}$ & $p$ & $\mathrm{~N}$ & Taxa & $\begin{array}{l}\text { Mean } \\
\%\end{array}$ \\
\hline Reykjavik $^{1}$ & $a, b$ & 142 & 8.2 & -1.0 & 0.2 & 0.000 & 20 & 512 & 545 & 46.6 & 18.7 & 0.023 & 20 & 38 & 13.8 & 1.1 & 0.5 & 0.034 & 20 & $\mathrm{~b}$ & 100 \\
\hline Siauliai & $a, b, c, d$ & 78 & - & - & - & - & 6 & 8973 & - & - & - & - & 6 & 63 & - & - & - & - & 6 & $\mathrm{~b}$ & 73 \\
\hline Neustrelitz & $a, b, c, d$ & 53 & 20.6 & -0.2 & 1.1 & 0.878 & 16 & 9870 & 5846 & -240.8 & 292.4 & 0.423 & 17 & 75 & 19.7 & -0.1 & 1.0 & 0.925 & 16 & $b$ & 58 \\
\hline Derby & $a, b, c, d$ & 49 & 18.0 & -1.8 & 0.6 & 0.005 & 19 & 3622 & 2313 & 116.0 & 89.5 & 0.212 & 19 & 83 & 12.5 & -0.4 & 0.5 & 0.393 & 19 & $\mathrm{~b}$ & 68 \\
\hline Leiden & $a, b, c, d$ & 35 & 19.5 & -1.0 & 0.8 & 0.235 & 19 & 7865 & 3464 & -187.5 & 130.7 & 0.169 & 20 & 102 & 41.7 & 0.3 & 1.8 & 0.846 & 19 & $a$ & 49 \\
\hline Łodz & $a, b, c, d$ & 67 & - & - & - & - & 4 & 17325 & - & - & - & - & 4 & 59 & - & - & - & - & 4 & $\mathrm{~b}$ & 79 \\
\hline Prague $^{2}$ & $a, b, c, d, e$ & 72 & - & - & - & - & 7 & 10821 & 5241 & 44.7 & 283.7 & 0.877 & 15 & 52 & - & - & - & - & 7 & $\mathrm{~b}$ & 84 \\
\hline Strasbourg $^{2}$ & $a, b, c, d$ & 56 & - & - & - & - & 6 & 9281 & 5222 & 141.5 & 217.2 & 0.525 & 17 & 79 & - & - & - & - & 6 & $\mathrm{~b}$ & 50 \\
\hline Zürich & $a, b, c, d, e$ & 39 & 20.3 & 0.1 & 0.8 & 0.921 & 20 & 14921 & 4948 & 454.1 & 165.6 & 0.013 & 20 & 87 & 18.4 & 0.1 & 0.7 & 0.852 & 20 & $\mathrm{~b}$ & 66 \\
\hline Legnano $^{3}$ & $a, b, c, d, e, f, g$ & 41 & 9.3 & -0.1 & 0.6 & 0.824 & 14 & 8311 & 4498 & 470.6 & 246.6 & 0.079 & 15 & 107 & 19.6 & -0.8 & 1.2 & 0.502 & 14 & $f$ & 67 \\
\hline Sofia & $a, b, c, d$ & 71 & 24.8 & -5.7 & 1.2 & 0.001 & 11 & 5904 & 2021 & 165.5 & 174.0 & 0.366 & 11 & 56 & 25.6 & 6.0 & 1.2 & 0.001 & 11 & $\mathrm{~b}$ & 74 \\
\hline Thessaloniki & $a, b, c, d$ & 48 & 8.2 & -0.0 & 0.3 & 0.989 & 20 & 533 & 357 & 26.5 & 12.8 & 0.053 & 20 & 97 & 12.8 & -0.6 & 0.5 & 0.237 & 20 & $\begin{array}{l}\text { c } \\
d\end{array}$ & $\begin{array}{l}40 \\
41 \\
\end{array}$ \\
\hline Madrid $^{4}$ & $a, b, d$ & - & - & - & - & - & - & 169 & 99 & -1.16 & 5.6 & 0.839 & 15 & - & - & - & - & - & - & $\mathrm{a}$ & 62 \\
\hline
\end{tabular}

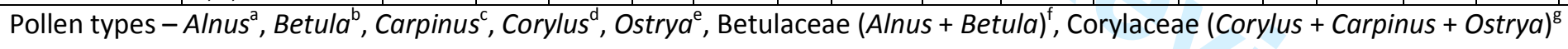

${ }^{1}$ The majority of Betulaceae pollen recorded at Reykjavik was from Betula (99.8\%) and only a small amount of Alnus pollen was registered.

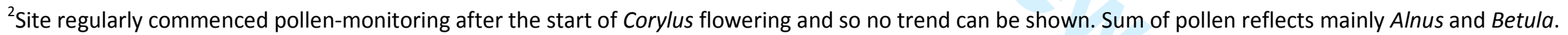

${ }^{3}$ Legnano changed from simply recording Betulaceae and Corylaceae pollen to recording Alnus, Betula, Carpinus, Corylus and Ostrya pollen in 2009.

${ }^{4}$ Betulaceae pollen counts at Madrid are intermittent and highly variable (from 33 to 356 grains in a year), it was therefore not possible to calculate start and end of the season. 
Table 2. Start dates, intensity (sum of pollen recorded in the season) and duration of Oleaceae pollen seasons recorded at 13 pollen-monitoring stations included in this study. The following statistics are included: the mean, Standard Deviation (SD), slope of the regression over time, Standard Error of the regression slope (SE), probability level $(p)$ and number of years in the analysis (N).

\begin{tabular}{|c|c|c|c|c|c|c|c|c|c|c|c|c|c|c|c|c|c|c|c|c|c|}
\hline \multirow[t]{2}{*}{$\begin{array}{c}\text { Pollen-monitoring } \\
\text { station }\end{array}$} & \multirow[t]{2}{*}{$\begin{array}{l}\text { Pollen } \\
\text { types }\end{array}$} & \multicolumn{6}{|c|}{ Start (DOY) } & \multicolumn{6}{|c|}{ Sum Year (grains) } & \multicolumn{6}{|c|}{ Duration (days) } & \multicolumn{2}{|c|}{$\begin{array}{c}\text { Most dominant } \\
\text { taxa }\end{array}$} \\
\hline & & Mean & SD & Slope & SE & $p$ & $\mathrm{~N}$ & Mean & SD & Slope & SE & $p$ & $\mathrm{~N}$ & Mean & SD & Slope & $\mathrm{SE}$ & $p$ & $\mathrm{~N}$ & Taxa & Mean \% \\
\hline Reykjavik $^{1}$ & NA & - & - & - & - & $2-$ & - & - & - & - & - & - & - & - & - & - & - & - & - & - & - \\
\hline Siauliai & $\mathrm{i}$ & 113 & - & - & - & - & 5 & 200 & - & - & - & - & 5 & 32 & - & - & - & - & 5 & $\mathrm{i}$ & 100 \\
\hline Neustrelitz & $h, i, j$, & 95 & 9.9 & -0.3 & 0.5 & 0.604 & 16 & 348 & 233 & 5.8 & 11.8 & 0.631 & 16 & 40 & 26.4 & -1.2 & 1.3 & 0.374 & 16 & $\mathrm{i}$ & 99 \\
\hline Derby & $h, i, j, n$ & 83 & 16.0 & 0.4 & 0.6 & 0.525 & 20 & 913 & 681 & 31.7 & 26.1 & 0.240 & 20 & 57 & 33.1 & -3.4 & 1.0 & 0.004 & 20 & $\mathrm{i}$ & 94 \\
\hline Leiden & $h, i, j$ & 81 & 15.6 & 0.7 & 0.6 & 0.296 & 19 & 1300 & 922 & -7.6 & 36.9 & 0.840 & 19 & 67 & 41.4 & -2.1 & 1.6 & 0.201 & 19 & $i$ & 96 \\
\hline Łodz & $\mathrm{i}$ & 103 & - & - & - & - & 4 & 990 & - & - & - & - & 4 & 34 & - & - & - & - & 4 & $\mathrm{i}$ & 100 \\
\hline Prague & $i, j$, & 89 & 11.5 & 0.2 & 0.6 & 0.737 & 15 & 1543 & 926 & -12.9 & 50.0 & 0.801 & 15 & 35 & 20.7 & -1.6 & 1.0 & 0.142 & 15 & $\mathrm{i}$ & 99 \\
\hline Strasbourg & $h, i, j$, & 75 & 14.4 & 0.3 & 0.7 & 0.669 & 15 & 2250 & 1268 & 24.7 & 54.3 & 0.656 & 17 & 48 & 25.1 & -0.5 & 1.3 & 0.696 & 15 & $\mathrm{i}$ & 99 \\
\hline Zurich $^{2}$ & $\mathrm{i}, \mathrm{m}$ & 86 & 10.7 & 0.2 & 0.4 & 0.659 & 19 & 5750 & 3261 & 42.5 & 135.9 & 0.759 & 19 & 35 & 13.6 & -0.1 & 0.6 & 0.875 & 19 & $i$ & 99 \\
\hline Legnano & $i, j, k, l, m$ & 76 & 12.9 & -0.7 & 0.8 & 0.413 & 15 & 1065 & 894 & 82.4 & 50.5 & 0.127 & 15 & 94 & 17.4 & 0.1 & 1.1 & 0.953 & 15 & 1 & 100 \\
\hline Sofia & $i, j$, & 77 & 15.3 & -1.1 & 1.0 & 0.275 & 12 & 2036 & 1408 & 65.5 & 86.8 & 0.466 & 13 & 41 & 14.1 & 0.6 & 0.9 & 0.530 & 12 & $\mathrm{i}$ & 99 \\
\hline Thessaloniki & $\mathrm{k}$ & 94 & 12.7 & -0.2 & 0.5 & 0.752 & 20 & 853 & 407 & 20.0 & 15.5 & 0.214 & 20 & 78 & 15.3 & 0.0 & 0.6 & 0.951 & 20 & $\mathrm{k}$ & 100 \\
\hline Madrid & $\mathrm{i}, \mathrm{j}, \mathrm{k}$ & 20 & 9.5 & 0.3 & 0.7 & 0.668 & 13 & 1870 & 815 & -113.2 & 39.9 & 0.015 & 14 & 158 & 19.2 & -0.3 & 1.3 & 0.826 & 13 & $\mathrm{k}$ & 64 \\
\hline
\end{tabular}

Pollen types - Forsythia ${ }^{\mathrm{h}}$, Fraxinus $^{\mathrm{i}}$, Ligustrum $^{\mathrm{j}}$, Olea $^{\mathrm{k}}$, Oleaceae $^{\mathrm{l}}$, other Oleaceae ${ }^{\mathrm{m}}$, Syringa $^{\mathrm{n}}$

${ }^{1}$ No Oleaceae pollen recorded at Reykjavik

${ }^{2}$ Note that only Fraxinus excelsior pollen grains are recorded as "Fraxinus" pollen in Zurich. Low amounts of Fraxinus ornus pollen are also seen in the samples, but these are recorded as "other Oleaceae". 


\section{Page 41 of 42}

Allergy

Table 3. Start dates, intensity (sum of pollen recorded in the season) and duration of Poaceae pollen seasons recorded at 13 pollen-monitoring stations included in this study. The following statistics are included: the mean, Standard Deviation (SD), slope of the regression over time, Standard Error of the regression slope (SE), probability level $(p)$ and number of years in the analysis (N).

\begin{tabular}{|c|c|c|c|c|c|c|c|c|c|c|c|c|c|c|c|c|c|c|c|c|c|}
\hline \multirow[t]{2}{*}{$\begin{array}{l}\text { Pollen-monitoring } \\
\text { station }\end{array}$} & \multirow[t]{2}{*}{$\begin{array}{l}\text { Pollen } \\
\text { types }\end{array}$} & \multicolumn{6}{|c|}{ Start (DOY) } & \multicolumn{6}{|c|}{ Sum Year (grains) } & \multicolumn{6}{|c|}{ Duration (days) } & \multicolumn{2}{|c|}{$\begin{array}{l}\text { Most dominant } \\
\text { taxa }\end{array}$} \\
\hline & & Mean & SD & Slope & SE & $p$ & $\mathrm{~N}$ & Mean & SD & Slope & SE & $p$ & $\mathrm{~N}$ & Mean & SD & Slope & SE & $p$ & $\mathrm{~N}$ & Taxa & Mean \% \\
\hline Reykjavik & $p$ & 174 & 6.0 & -0.5 & 0.2 & 0.020 & 20 & 1747 & 707 & 35.6 & 26.9 & 0.202 & 20 & 69 & 9.4 & -0.4 & 0.4 & 0.254 & 20 & $p$ & 100 \\
\hline Siauliai & $p, q$ & 158 & - & - & - & - & 6 & 2007 & - & - & - & - & 6 & 83 & - & - & - & - & 6 & $p$ & 99 \\
\hline Neustrelitz & $p, q, r$ & 142 & 9.6 & -0.7 & 0.4 & 0.141 & 14 & 3100 & 1059 & -52.2 & 47.8 & 0.291 & 18 & 93 & 20.6 & 2.7 & 0.7 & 0.001 & 14 & $p$ & 97 \\
\hline Derby & $p$ & 145 & 10.6 & 0.1 & 0.4 & 0.841 & 20 & 5467 & 1995 & 85.3 & 76.9 & 0.282 & 20 & 91 & 19.5 & -2.2 & 0.6 & 0.002 & 20 & $p$ & 100 \\
\hline Leiden & $p$ & 133 & 9.7 & -0.5 & 0.4 & 0.220 & 20 & 5122 & 1898 & -231.8 & 52.3 & 0.000 & 20 & 118 & 10.5 & 0.4 & 0.4 & 0.305 & 20 & $p$ & 100 \\
\hline Łodz $^{1}$ & $o, p, q$ & 142 & - & - & - & - & 2 & 3874 & - & - & - & 0.681 & 5 & 82 & - & - & - & - & 2 & $p$ & 95 \\
\hline Prague & $p, q, r$ & 136 & 6.7 & -0.7 & 0.4 & 0.138 & 13 & 2946 & 1758 & -211.6 & 101.3 & 0.061 & 13 & 92 & 17.2 & 0.3 & 1.2 & 0.822 & 13 & $p$ & 98 \\
\hline Strasbourg & $p$ & 130 & 7.7 & -0.9 & 0.3 & 0.021 & 11 & 2942 & 1145 & -40.8 & 48.7 & 0.414 & 18 & 94 & 19.5 & -1.3 & 1.0 & 0.221 & 11 & $p$ & 100 \\
\hline Zürich & $p, q$ & 133 & 5.7 & -0.2 & 0.2 & 0.290 & 20 & 3753 & 788 & 51.6 & 28.9 & 0.091 & 20 & 96 & 10.6 & -0.1 & 0.4 & 0.793 & 20 & $p$ & 100 \\
\hline Legnano & $p$ & 105 & 7.6 & -0.2 & 0.5 & 0.650 & 15 & 4250 & 1551 & 182.1 & 81.9 & 0.044 & 15 & 148 & 13.7 & 0.3 & 0.8 & 0.736 & 15 & $p$ & 100 \\
\hline Sofia & $p$ & 126 & 11.6 & 0.1 & 0.6 & 0.874 & 16 & 3736 & 1601 & -101.8 & 64.9 & 0.136 & 18 & 114 & 16.1 & 1.0 & 0.7 & 0.183 & 16 & $p$ & 100 \\
\hline Thessaloniki & $p$ & 98 & 16.1 & 0.0 & 0.6 & 0.998 & 20 & 591 & 339 & 24.3 & 12.2 & 0.063 & 20 & 152 & 38.7 & 3.0 & 1.4 & 0.045 & 20 & $p$ & 100 \\
\hline Madrid $^{1}$ & $p$ & 58 & - & - & - & - & 4 & 3141 & 2123 & -95.9 & 126.1 & 0.464 & 12 & 211 & - & - & - & - & 4 & $p$ & 100 \\
\hline
\end{tabular}

Pollen types - Cerealia ${ }^{\circ}$, Poaceae ${ }^{p}$, Secale ${ }^{q}$, Zea mays $^{r}$

${ }^{1}$ Monitoring station did not operate continuously and so it was not always possible to calculate start and end of the season. However, it was still possible to calculate intensity. 
Table 4. Start dates, intensity (sum of pollen recorded in the season) and duration of Asteraceae pollen seasons recorded at 13 pollen-monitoring stations included in this study. The following statistics are included: the mean, Standard Deviation (SD), slope of the regression over time, Standard Error of the regression slope (SE), probability level ( $p$ ) and number of years in the analysis (N).

\begin{tabular}{|c|c|c|c|c|c|c|c|c|c|c|c|c|c|c|c|c|c|c|c|c|c|}
\hline \multirow[t]{2}{*}{$\begin{array}{l}\text { Pollen-monitoring } \\
\text { station }\end{array}$} & \multirow[t]{2}{*}{$\begin{array}{l}\text { Pollen } \\
\text { types }\end{array}$} & \multicolumn{6}{|c|}{ Start (DOY) } & \multicolumn{6}{|c|}{ Sum Year (grains) } & \multicolumn{6}{|c|}{ Duration (days) } & \multicolumn{2}{|c|}{$\begin{array}{l}\text { Most dominant } \\
\text { taxa }\end{array}$} \\
\hline & & Mean & SD & Slope & $\mathrm{SE}$ & $p$ & $\mathrm{~N}$ & Mean & SD & Slope & SE & $p$ & $\mathrm{~N}$ & Mean & SD & Slope & SE & $p$ & $\mathrm{~N}$ & Taxa & Mean \% \\
\hline Reykjavik $^{1}$ & $t, u, v, x$ & 161 & - & - & - & - & 5 & 54 & - & - & - & - & 5 & 90 & - & - & - & - & 5 & $v+x$ & 92 \\
\hline Siauliai & $\mathrm{s}, \mathrm{t}, \mathrm{u}$ & 202 & - & - & - & - & 7 & 2168 & - & - & - & - & 7 & 40 & - & - & - & - & 7 & $\mathrm{t}$ & 97 \\
\hline Neustrelitz & $s, t, u, v$ & 181 & 22.0 & 0.2 & 1.1 & 0.830 & 15 & 777 & 261 & -17.2 & 12.0 & 0.174 & 15 & 67 & 27.1 & 1.6 & 1.3 & 0.222 & 15 & $\mathrm{t}$ & 88 \\
\hline Derby & $s, t, x$ & 153 & 33.9 & -3.4 & 1.1 & 0.005 & 20 & 80 & 42 & -3.6 & 1.5 & 0.022 & 20 & 115 & 43.0 & 1.3 & 1.7 & 0.440 & 20 & $\mathrm{t}$ & 97 \\
\hline Leiden & $\mathrm{s}, \mathrm{t}, \mathrm{u}$ & 167 & 28.8 & -0.2 & 1.1 & 0.850 & 20 & 491 & 320 & -46.6 & 6.1 & 0.000 & 19 & 84 & 29.3 & 0.7 & 1.2 & 0.545 & 20 & $\mathrm{t}$ & 87 \\
\hline Łodz $^{1}$ & $\mathrm{~s}, \mathrm{t}$ & 191 & - & - & - & - & 3 & 994 & - & - & - & - & 3 & 64 & - & - & - & - & 3 & $\mathrm{t}$ & 85 \\
\hline Prague & $\mathrm{s}, \mathrm{t}, \mathrm{u}, \mathrm{v}$ & 197 & 13.1 & 0.9 & 0.7 & 0.229 & 15 & 1534 & 1126 & -107.6 & 54.7 & 0.069 & 16 & 60 & 17.0 & -0.9 & 1.0 & 0.387 & 15 & $\mathrm{t}$ & 82 \\
\hline Strasbourg & $s, t, u, v$ & 147 & 29.2 & -0.7 & 1.2 & 0.568 & 19 & 237 & 112 & -12.8 & 3.3 & 0.001 & 19 & 105 & 32.5 & 0.5 & 1.3 & 0.685 & 19 & $\mathrm{t}$ & 74 \\
\hline Zürich & $s, t, u$ & 122 & 17.4 & -0.5 & 0.7 & 0.452 & 20 & 82 & 35 & 1.1 & 1.4 & 0.418 & 20 & 138 & 18.4 & 0.9 & 0.7 & 0.199 & 20 & $\begin{array}{l}\mathrm{u} \\
\mathrm{t}\end{array}$ & $\begin{array}{l}42 \\
33 \\
\end{array}$ \\
\hline Legnano & $\mathrm{s}, \mathrm{t}, \mathrm{u}$ & 219 & 3.6 & -0.2 & 0.2 & 0.441 & 15 & 5393 & 1224 & 71.7 & 73.3 & 0.346 & 15 & 53 & 7.4 & 0.1 & 0.5 & 0.783 & 15 & $\mathrm{~s}$ & 90 \\
\hline Sofia & $s, t, u, v$ & 188 & 13.4 & 0.3 & 1.0 & 0.744 & 13 & 1281 & 416 & -29.3 & 31.0 & 0.365 & 13 & 78 & 15.7 & 0.5 & 1.2 & 0.713 & 13 & $\begin{array}{l}\mathrm{s} \\
\mathrm{t}\end{array}$ & $\begin{array}{l}42 \\
54 \\
\end{array}$ \\
\hline Thessaloniki & $s, t, u, v$ & 124 & 35.5 & 0.2 & 1.5 & 0.919 & 19 & 148 & 63 & -1.3 & 2.7 & 0.636 & 19 & 152 & 39.3 & 0.3 & 1.7 & 0.881 & 19 & $\begin{array}{l}\mathrm{s} \\
\mathrm{t}\end{array}$ & $\begin{array}{l}45 \\
36 \\
\end{array}$ \\
\hline Madrid $^{1}$ & $\mathrm{t}, \mathrm{w}$ & 92 & 50.3 & -3.5 & 2.8 & 0.227 & 15 & 160 & 130 & -13.1 & 6.7 & 0.070 & 15 & 196 & 67.3 & 0.7 & 3.9 & 0.868 & 15 & $w$ & 70 \\
\hline
\end{tabular}

Pollen types - Ambrosia ${ }^{\mathrm{s}}$, Artemisia $^{\mathrm{t}}$, Asteraceae ${ }^{\mathrm{u}}$, Cichoriaceae ${ }^{\mathrm{v}}$, Compositae (Asteraceae) $^{\mathrm{w}}$, , $^{\text {(araxacum }}{ }^{\mathrm{x}}$

${ }^{1}$ Reykjavik - Asteraceae pollen were only recorded from 2005 to 2009. Cichoriaceae and Taraxacum were counted separately in 2005 and 2009. However, in other years only Taraxacum was counted. Therefore Cichoriaceae and Taraxacum have been combined to produce the most dominant taxa (2005-2009). 